\title{
The Farsund Shear Zone: geochemical evidence for lithological diversity in the wall rock of the Rogaland Anorthosite Province, South Norway
}

\author{
Jean-Clair Duchesne ${ }^{1} \&$ Jan Hertogen ${ }^{2}$ \\ ${ }^{1}$ Department of Geology, University of Liège (Belgium), Quartier Agora, B2O, Allée du Six-Août, 12, B-4000 \\ Liège, Belgium \\ ${ }^{2}$ Department of Earth and Environmental Sciences, Afdeling Geologie, KU Leuven (Belgium) \\ E-mail corresponding author (Jean-Clair Duchesne): jc.duchesne@uliege.be
}

Keywords:

- Sirdal magmatic belt

- suldal arc

- Sveconorwegian

- AMCG

- Rogaland Anorthosite Province

- Electronic Supplement 1. Metabasite samples

- Electronic Supplement 2. Granitoid samples

- Electronic Supplement 3. Whole-rock geochemistry

Received:

5. February 2020

Accepted:

11. November 2020

Published online:

18. March 2021

The Rogaland Anorthosite Province (RAP) - a typical Proterozoic Anorthosite-MangeriteCharnockite (AMC) plutonic complex exposed in the Sveconorwegian orogen in South Norway-was emplaced diapirically through the crust, along a shear zone, at c. 933-916 Ma. The shear zone, recently defined as the Farsund Shear Zone (FSZ), crops out along the eastern flank of the anorthosite province, and it is made up of strongly foliated, steeply dipping, banded gneisses. The banded gneisses comprise a diversity of lithologies: metabasites, granitoid gneisses, augen gneisses and kinzigitic gneisses. Major and trace element compositions of samples mostly from the banded gneisses and the neighbouring granite gneiss permit us to unravel the nature of the various protoliths. The kinzigitic gneisses result from metamorphism of pelitic sediments, while the augen gneisses belong to the high-K calc-alkaline series similar to the Feda suite (c. $1050 \mathrm{Ma}$ ), a major component of the Sirdal magmatic belt (SMB, 1070-1020 Ma). The metabasites comprise jotunites comparable to the intermediate rocks of the AMC suite (933-916 Ma) as well as amphibolites and norites with trace element signatures consistent with an oceanic origin. Charnockitic gneisses could result from anatexis in $\mathrm{CO}_{2}$-rich conditions or from fractionation of felsic magma similar to that of the charnockite-grante Farsund intrusion (931-926 Ma). Some leucogranitic layers have a typical REE distribution of migmatitic leucosome. Other granite layers can be distinguished from the massive granite gneiss that has higher $\mathrm{Th}, \mathrm{Pb}$ and $\mathrm{Rb}$ concentrations and $[\mathrm{La} / \mathrm{Yb}]_{N}$ ratios, but all granites display high-K calc-alkaline affinities compatible with an island-arc origin. The granite gneiss is comparable to the SMB rocks and the granite layers to the Suldal arc lithologies (c. 1520-1480 Ma). The FSZ hosts thin interleaved layers of rocks corresponding to the major lithologies exposed at regional scale. This includes jotunites and charnockites probably genetically related to intrusion of the c. $930 \mathrm{Ma}$ anorthosite province, and a variety of granitic gneisses, metasedimentary rocks, augen gneisses, and mafic rocks with protolith ages ranging from c. $1020 \mathrm{Ma}$ to c. $1500 \mathrm{Ma}$.

Duchesne, J.-C. \& Hertogen, J. 2021: The Farsund Shear Zone: geochemical evidence for lithological diversity in the wall rock of the Rogaland Anorthosite Province, South Norway. Norwegian Journal of Geology 100, 202020. https://dx.doi.org/10.17850/njg100-4-3. 


\section{Introduction}

Diapiric rise of anorthosite through ductile migmatites is the dominant mechanism of emplacement of the large anorthosite massifs in the Rogaland anorthosite province (RAP) (Duchesne, 1984; Barnichon et al., 1999; Charlier et al., 2010). This diapirism may have been facilitated by a shear zone as suggested by the occurrence of a crustal size geophysical discontinuity revealed by deep seismic data (Andersson et al., 1996), and synthesised in the crustal tongue model of Duchesne et al. (1999). A component of this shear zone has been recently defined on the eastern flank of the magmatic province and called the Farsund Shear Zone (FSZ) (Bolle et al., 2010). This shear zone coincides with a unit of banded gneiss, interlayered with thin units of granitic gneiss and augen gneiss (Falkum 1982, 1985; Marker et al., 2003).

We investigate here the petrology and geochemical compositions of various lithologies outcropping mainly in the banded gneisses near the RAP in the FSZ north of the Hidra anorthosite intrusion (Demaiffe et al., 1973; Demaiffe \& Hertogen, 1981; Duchesne et al., 2001) and the Farsund charnockite-granite intrusion(VanderAuweraetal.,2014a), andalsofarthertotheeast, inthe Rogaland-VestAgdergneisscomplex (Falkum, 1982, 1985) (Figs. 1, 2 \& 3). We show that various types of mafic and felsic rocks produced at

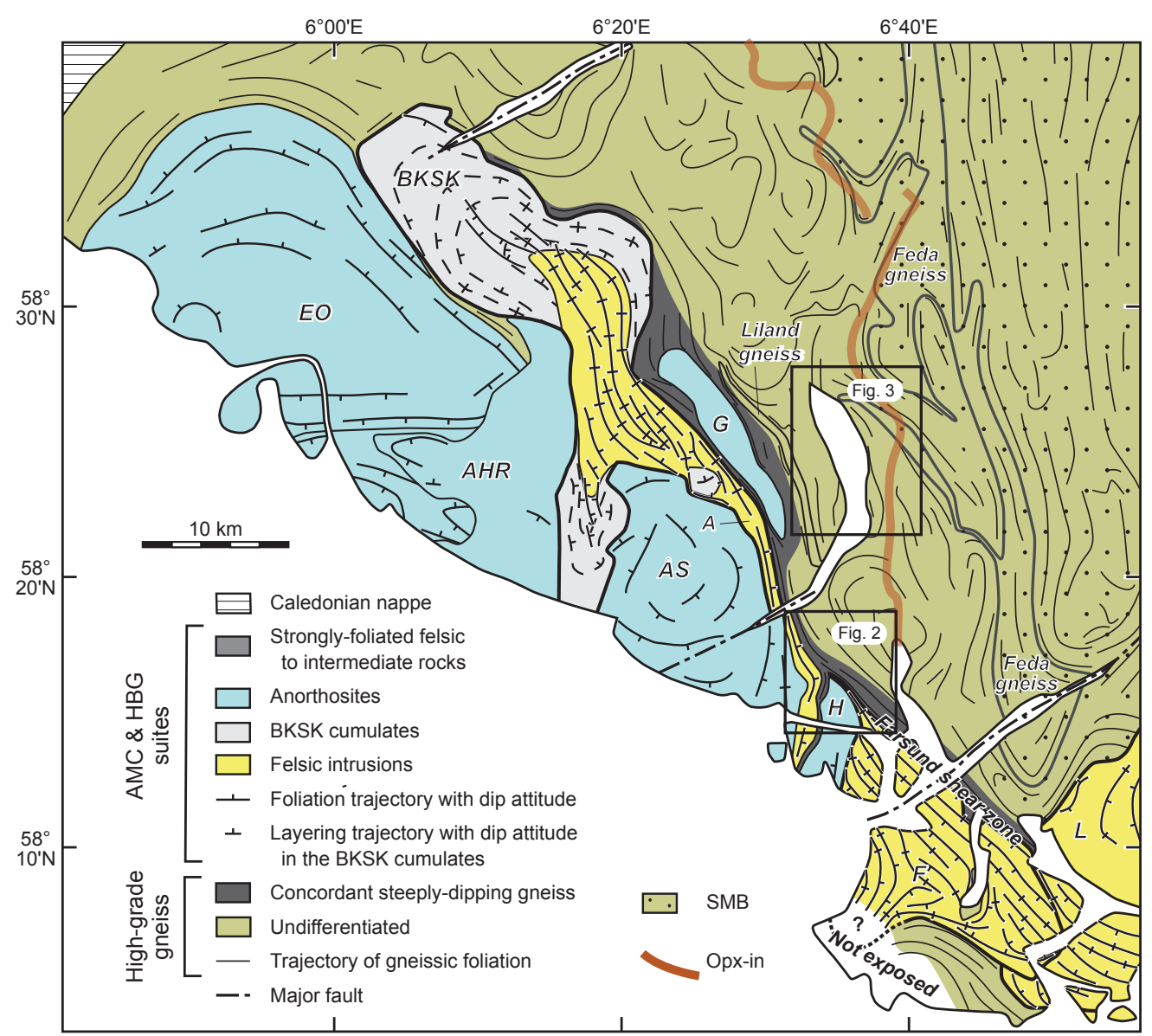

Figure 1. Schematic structural map of the Rogaland Anorthosite Province (RAP), Farsund intrusion and adjacent areas, highlighting foliation trajectories. Adapted from Bolle et al. (2010). The Sirdal magmatic belt (SMB) after Coint et al. (2015) and Slagstad et al. (2018). The orthopyroxene-in isograd after Falkum (1982). Abbreviations: EO Egersund-Ogna anorthosite, AHR-Amdal-Helleren-Rodland anorthosite, ÅS-Åna-Sira anorthosite, BKSK-BjerkreimSokndal layered intrusion and $A$ - its apophysis, $H$ - Hidra anorthosite, $G$ - Garsaknatt anorthosite, F - charnockitegranite Farsund intrusion, L - Lyngdal granodiorite, AMC - anorthosite-mangerite-charnockite, HBG - hornblende biotite granite. Foliation trajectories are drawn from foliation and igneous layering in the anorthosite bodies, igneous modal layering in the cumulates of the BKSK layered intrusion, and igneous and magnetic foliations in the Farsund and Lyngdal intrusions, as well as in the BKSK felsic rocks and the Apophysis. The concordant steeply dipping gneisses along the eastern margin of the RAP delineate the Farsund Shear Zone. 

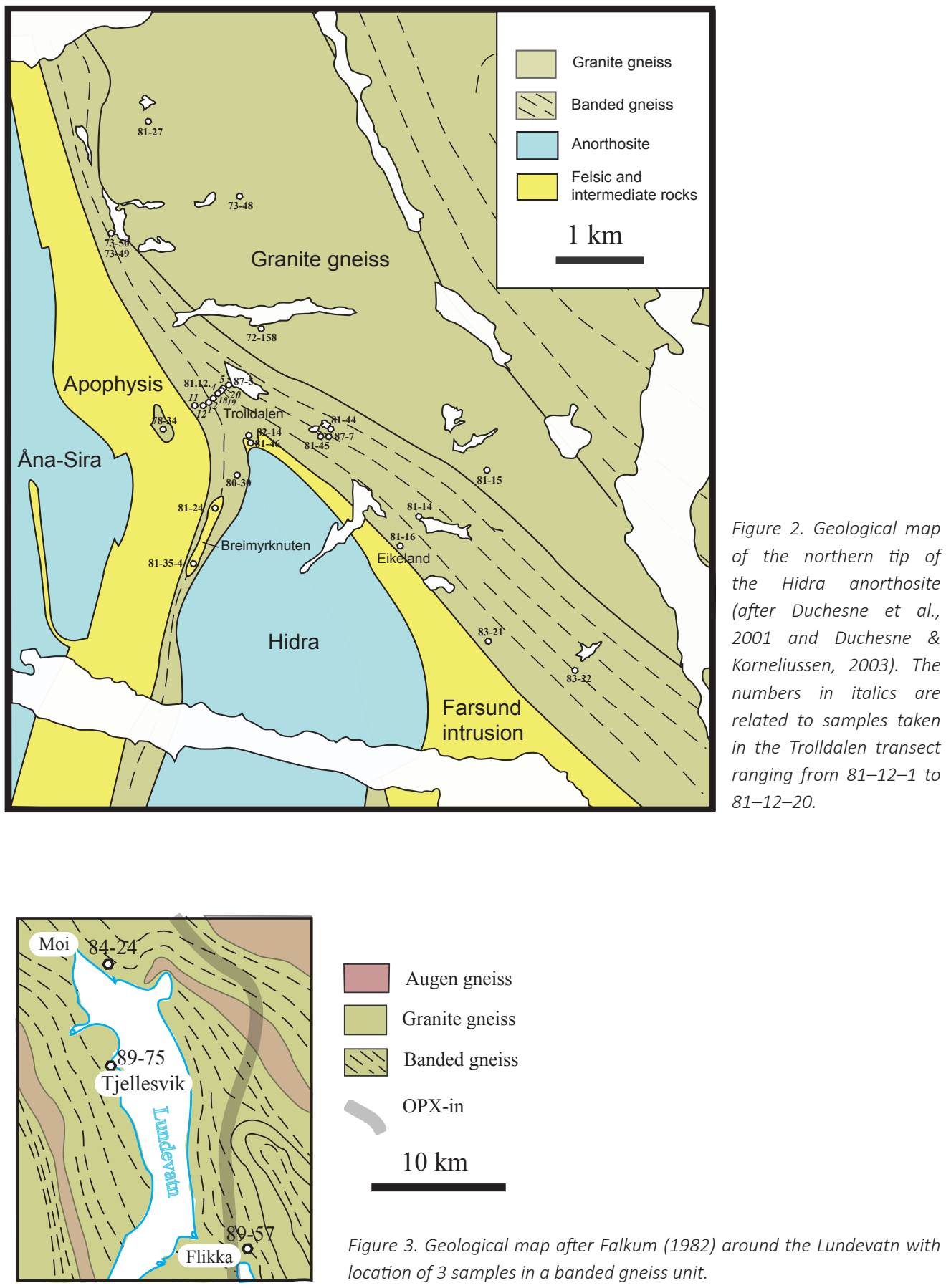

\section{Augen gneiss}

Granite gneiss

I․․ Banded gneiss

OPX-in

$10 \mathrm{~km}$

Figure 3. Geological map after Falkum (1982) around the Lundevatn with location of 3 samples in a banded gneiss unit.

various depths from tapping different sources (the crustal zone concept of Annen et al., 2006) have intruded this shear zone. Most intrusions are coeval with the RAP but we provide geochemical evidence that some could be related to older phases in the evolution of the gneiss complex, possibly up to 1500 Ma. The FSZ might have been active for a long interval of time.

\section{Geological context}

We have investigated metamorphic rocks in the wall rock of the RAP based on the geological maps of Falkum (1982) and Marker et al. (2003) (Figs. 2 \& 3). Three types of lithological units are distinguished 
in the field at regional scale: (1) augen gneiss; (2) banded gneiss which comprises different phases of grey granitic gneiss with sporadic amphibolitic (noritic) and metasedimentary (pelite, quartzite) layers (Marker et al., 2003) (also defined as locally migmatitic by Falkum, 1982); (3) granitic gneiss, grey, weakly foliated. Recent field work, petrographic studies, geochemical analyses and geochronological data (Slagstad et al., 2013, 2018; Coint et al., 2015) have revealed that east of the orthopyroxene-in (opx-in) isograd (Falkum, 1982; Tobi et al., 1985; Maijer \& Padget, 1987), the 3 lithological units belong to the 1070-1010 Ma Sirdal Magmatic Belt (SMB) that is a composite NNW-SSE-trending granitoid batholith, comprising elongate and variably foliated plutons of granodiorite, granite and leucogranite (Slagstad et al., 2013; Bingen et al, 2015; Coint et al., 2015). Thin banded gneiss units, interleaved within granitoid plutons, have been interpreted as xenoliths or panels of older wall rocks (Coint et al., 2015). The granitoids intruded in pressure conditions of 0.38-0.48 GPa (Coint et al., 2015), between $1066 \pm$ 10 and $1020 \pm 15$ Ma (Bingen \& van Breemen, 1998; Möller et al., 2002; Slagstad et al., 2013, 2018; Bingen et al., 2015; Coint et al., 2015). A large part of the belt is made up of silica-rich biotite granite to leucogranite. Plutons of biotite + amphibole $\mathrm{K}$-feldspar-phyric quartz-monzonite to granodiorite are specifically called the Feda suite (1050 $\pm 8 \mathrm{Ma})$ and Fennefoss augen gneiss (1031 $\pm 2 \mathrm{Ma}$ ) (Bingen \& van Breemen, 1998). These are characterised by a magnesian, high-K, high-Sr-Ba, calc-alkaline geochemical signature. An augen gneiss intrusion, the Liland body, occurs close to the RAP (Fig. 1) at some $15 \mathrm{~km}$ from the main SMB (Bingen, 1989). With an age of $1051 \pm 4 \mathrm{Ma}$ (Bingen \& van Breemen, 1998), it is considered as belonging to the SMB and represents an offshoot of the Feda suite (Fig. 1).

The studied region, located between the SMB and the RAP, is part of the pre-Sveconorwegian basement (the Hardangervidda Rogaland sector) that continues to the north and merges in the Mesoproterozoic Suldal Arc (Roberts et al., 2013) that comprises c. 1500 Ma amphibolitic to rhyodacitic gneisses, gabbroic to granitic gneisses, as well as granitoids.

In Rogaland, the high-grade gneisses of the basement have suffered two metamorphic cycles (Kars et al., 1980; Tobi et al., 1985). The first one (M1) of regional extension has culminated in UHT conditions in the upper amphibolite to granulite facies (Drüppel et al., 2013) in the time window between c. $1045 \mathrm{Ma}$ and c. $992 \mathrm{Ma}$ (Laurent et al., 2018a), and the second one (M2) has developed in an aureole around the AMC complex at c. $930 \mathrm{Ma}$ and has also reached UHT conditions (Laurent et al., 2018b). An orthopyroxene isograd in quartzo-feldspathic rocks (Figs. 1 \& 3) has been defined (Kars et al., 1980; Falkum, 1982) that shows a progressive $E$ to $W$ increase in metamorphic grade from amphibolite facies to granulite facies at the contact with the RAP. The two isograds that characterise the gneisses north of the Egersund-Ogna anorthosite and the Bjerkreim-Sokndal layered intrusion - an osumilite isograd in metasedimentary rocks and a pigeonite isograd in leucogranitic gneisses (Tobi et al., 1985) - have not been recognised in the studiedarea. However, Wilmart \& Duchesne (1987) provided evidence - from a hercynite+ quartz paragenesis armoured in porphyroblastic garnet in a kinzigitic gneiss (sample 81.12.1) $\neg$ that UHT conditions could have been reached in the banded gneisses close to the AMC complex (Fig. 2).

We mainly focused on rocks from the banded gneisses (Figs. $2 \& 3$ ) that comprise metabasites, augen gneisses, granitoids rocks and kinzigitic gneisses. Most samples were collected in the banded gneisses that crop out along the FSZ (Bolle et al., 2010) (Fig. 2). These samples were thus affected by the two cycles of metamorphism. Some samples (Fig. 3) are located near Lundevatn, more to the east, farther from the RAP, in another banded gneiss unit cropping out close to the SMB. These samples were clearly affected by the M2 cycle as shown by reaction rims between amphibolite and felsic lithologies (Tobi et al., 1985; Vander Auwera, 1993). We have also investigated samples from the granite gneiss unit that is exposed east of the FSZ (Fig. 2). All samples were strongly affected by several phases of deformation, particularly those located in the FSZ (Bolle et al., 2010).

The FSZ is described by Bolle et al. (2010). It is a NW-SE-trending, c. $70 \mathrm{~km}$-long up to $3 \mathrm{~km}$-thick, high-strain zone exposed along the northeastern contact of the RAP. It consists of granulite facies 
gneisses characterised by a steeply dipping tectonic lithological layering (or banding) (Fig. 1), recording extensional or transtensional deformation. The diversity of gneisses hosted in the shear zone are analysed hereafter. The timing of deformation clearly overlaps with the timing of emplacement of the Rogaland Anorthosite Province, i.e., 933-916 Ma (Schärer et al., 1996; Vander Auwera et al., 2011). $\mathrm{Re}-$ Os dating of molybdenite in quartz and quartzo-feldspathic layers (Gursli mines) range from $946 \pm 3$ to $917 \pm 3 \mathrm{Ma}$, recording mineralisation and deformation in the shear zone (Bingen et al., 2006).

\section{Methods of investigation}

Representative samples of the major lithologies have been collected. A short petrographic description of the samples is given in Electronic supplements $1 \& 2$. Detailed field relationships of most samples are described in guide books - locality 4.10 in Duchesne et al. (1987), and locality 4.3 in Duchesne \& Korneliussen (2003) - and for the samples around the lake Lundevatn in Vander Auwera (1993).

The samples were analysed for major and trace elements. X-Ray fluorescence on a CGR Lambda 2020 spectrometer (University of Liège) was used to analyse $\mathrm{Si}, \mathrm{Ti}, \mathrm{A} 1$, total $\mathrm{Fe}, \mathrm{Mn}, \mathrm{Mg}, \mathrm{Ca}, \mathrm{K}$ and $\mathrm{P}$ on $\mathrm{Li}$ borate glass discs, as well as $\mathrm{Na}, \mathrm{Rb}, \mathrm{Sr}, \mathrm{Zr}, \mathrm{Y}, \mathrm{Ni}, \mathrm{Co}, \mathrm{Zn}, \mathrm{V}, \mathrm{Cr}, \mathrm{Ba}, \mathrm{Ce}$, La and $\mathrm{Nd}$, on pressed powder pellets. FeO was measured by titration.

Instrumental neutron activation analyses for REE, U, Th, Ta, $\mathrm{Hf}, \mathrm{Sc}, \mathrm{Rb}$ and $\mathrm{Cr}$ were carried out at the Afdeling Fysico-Chemische Geologie, KUL, Leuven, under the supervision of Jan Hertogen. The agreement between the two methods is excellent. When several methods were used, the values from the NAA have been preferred.

\section{Lithological units}

\section{Metabasites}

Three types of metabasite have been documented in the banded gneiss units. They are characterized by their mineral paragenesis: 1 . hornblende-bearing amphibolitic metabasites; 2 . hornblende and biotite-bearing amphibolitic metabasites; 3. two-pyroxene noritic metabasites. A fourth type assembles samples from the other types that, whatever their mineralogy, have high $\mathrm{P}, \mathrm{Ti}$ and $\mathrm{Zr}$ contents, characters that are typical of jotunites (Fe-Ti-P-rich hypersthene diorites or monzonorites). This group is called jotunitic metabasites. Jotunites are typical members of the AMC plutonism, particularly in the RAP where they occur as chilled margins of the Bjerkreim-Sokndal and Hidra intrusions as well as in a large dyke system (Duchesne et al., 1989; Duchesne, 1990).

Sample locations and major and trace elements compositions are given in Electronic Supplement 3 and short petrographic features are reported in Electronic Supplement 1.

Most samples are coming from the FSZ (Fig. 2) where the various types are intimately mixed. It is particularly the case in Trolldalen (Fig. 2) where samples 81-12-20 and 81-12-12 are jotunitic, $81-12-11$ is a two-pyroxene norite, $81-12-2$ and $81-12-5$ are biotite-free amphibolites, and $87-5$ is a biotite-bearing amphibolite. Farther east from the RAP (but within the orthopyroxene isograd) (Fig. 3), samples 89-75 (Tjellesvik), 89-57 and 89-58 (Flikka) are biotite-bearing amphibolite and 84-24 (Moi) is a jotunitic metabasite. Thus, there are no apparent relationships between the metabasite types and the distance to the RAP. 
The geochemical contrast between the various types is shown in Figs. $4 \& 5$. The group of jotunitc rocks, defined by P2O5, TiO2 and Zr (Fig. 4A, B, D), tends to have a lower Mg\# and higher Ba and Ce compositions (Fig. $4 \mathrm{E}, \mathrm{F}$ ) than the other metabasites. For the other elements the jotunitic rocks are similar to the other types, thus of little help in the discrimination process.

Compared to the biotite-bearing amphibolites, the biotite-free amphibolites have lower $\mathrm{P}_{2} \mathrm{O}_{5}$ (Fig. 4A), $\mathrm{Zr}$ (Fig. 4D) and Ba (Fig. 4E) contents with lower REE contents and flatter REE distributions (Fig. 5). The $\mathrm{K}_{2} \mathrm{O}$ content of the biotite-bearing amphibolite is consistent with the presence of biotite in the mineral assemblage (Fig. 4C). Finally, the two-pyroxene noritic metabasites are similar to the biotite-bearing amphibolite for most elements but show higher values in $\mathrm{SiO}_{2}\left(52-56 \mathrm{SiO}_{2}\right)$ and lower $\mathrm{Mg \#}$ (c. 0.4) (Fig. 4F).

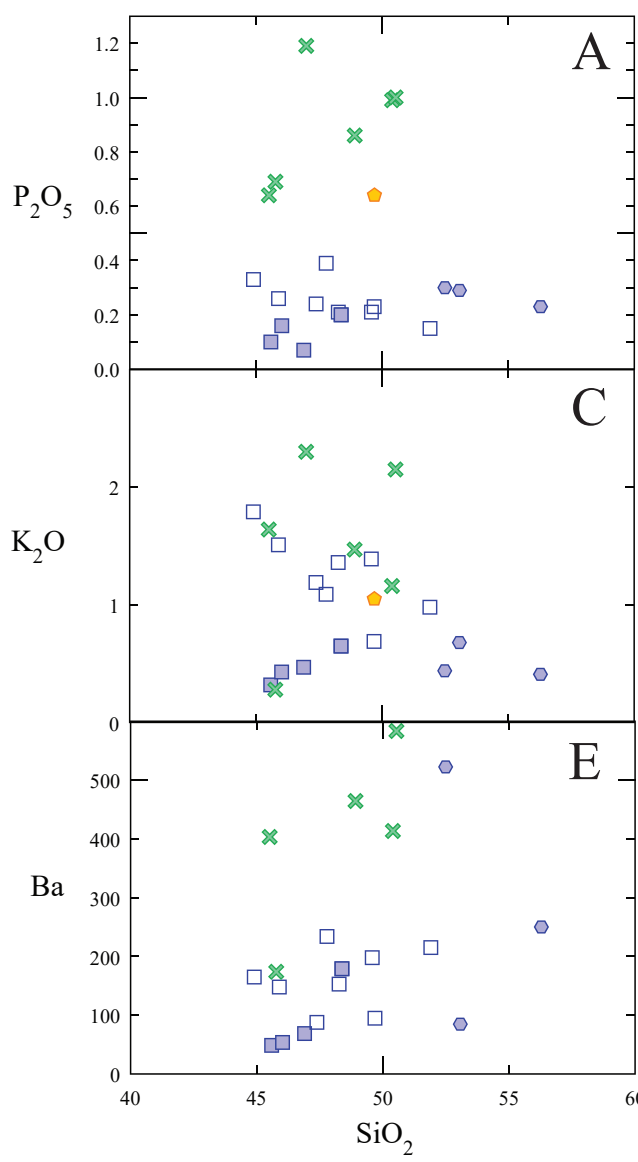

× Jotunitic metabasite

- Tjorn parental magma

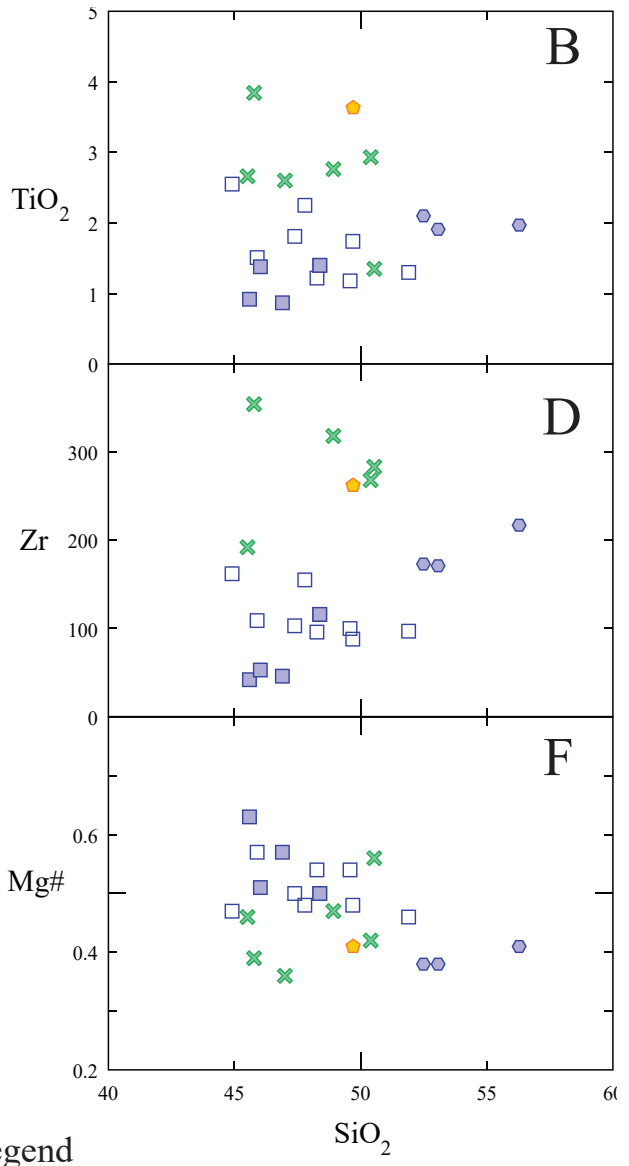

$\square \mathrm{Hbl}$ metabasite

$\square$ Biot + Hbl metabasite

- Pyroxene metabasite

Figure 4. Harker diagrams showing the discriminating characters of the jotunitic metabasites compared with the other metabasites. A typical jotunite composition (the Tjörn parental magma of Duchesne \& Hertogen, 1988) is also plotted to show its similarities with the jotunitic metabasites. 

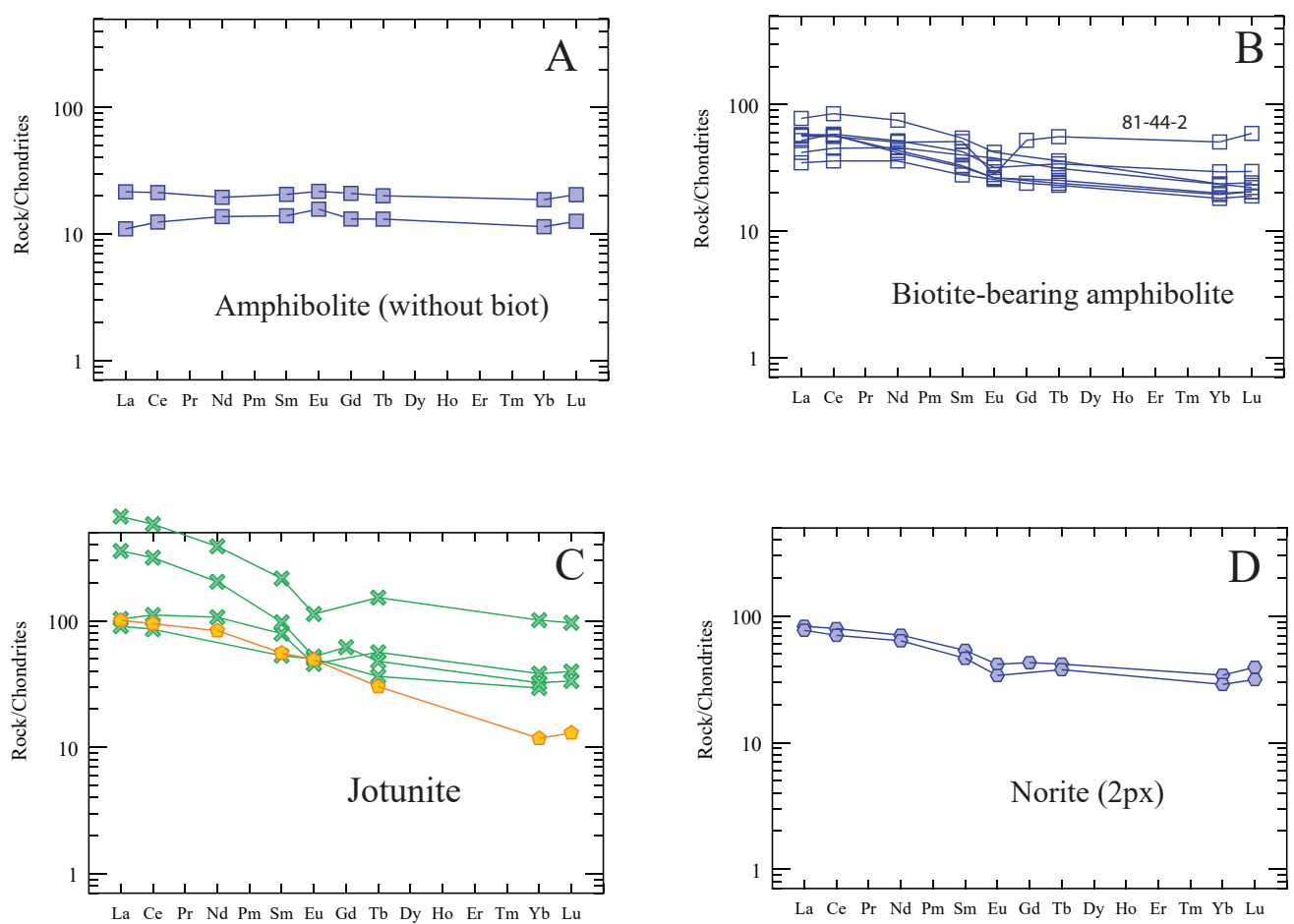

Figure 5. Chondrite-normalised REE distributions of the metabasites; see Figure 4 for symbols. Normalising values after Sun \& McDonough (1989)

\section{Paragneisses}

A paragneiss occurrence (sample 81.12.1; Fig. 2) in the banded gneiss unit close to the contact with the Apophysis (Trolldalen) has been documented. It is a kinzigitic gneiss that contains garnet, cordierite, sillimanite, $\mathrm{K}$-feldspar, plagioclase, hercynite, $\mathrm{Fe}-\mathrm{Ti}$ oxides and quartz. Armoured relics of spinel-quartz aggregates in garnet suggest that temperatures $>900^{\circ} \mathrm{C}$ were attained at c. $6 \mathrm{kbar}$ in the contact aureole of the RAP (Wilmart \& Duchesne, 1987). This gneiss locally shows evidence of migmatisation processes: sample 81.12.1B has a leucosome (L) associated with a melanosome (M); sample 81.12.1A is taken from the homogeneous part of the gneiss. Their major and trace element compositions are reported in Electronic Supplement 3.

\section{Augen gneisses}

Two augen gneiss occurrences have been sampled in the banded gneiss unit of the FSZ: 81.12.16 in Trolldalen and 81.16.3 in Eikeland (Fig. 2). They both contain K-feldspar megacrysts in a granoblastic matrix of equigranular grains of plagioclase, quartz, clinopyroxene, orthopyroxene, rare dactylitic biotite, apatite and zircon. The chemical compositions (Electronic Supplement 3) are compared to selected samples of the Feda and Liland augen gneisses (Bingen, 1989; Bingen et al., 1993) in Fig. 6. Both samples are calc-alkalic (Fig. 6A), magnesian (Fig. 6B), and belong to the high-K calcalkaline series (Fig. 6C). In Harker diagrams they are similar to the less evolved samples of the Feda suite (but have slightly lower Mg\#) (Fig. 6D). The REE content (Fig. 6E) is typically higher than in the Feda suite, and the spidergram (Fig. 6F) is similar with a less pronounced $\mathrm{Nb}$ negative anomaly and higher Zr contents. Although the Liland augen gneiss intrusion is located close to the FSZ (Fig. 2), Fig. 6 suggests that it is compositionally more differentiated and distinct. 

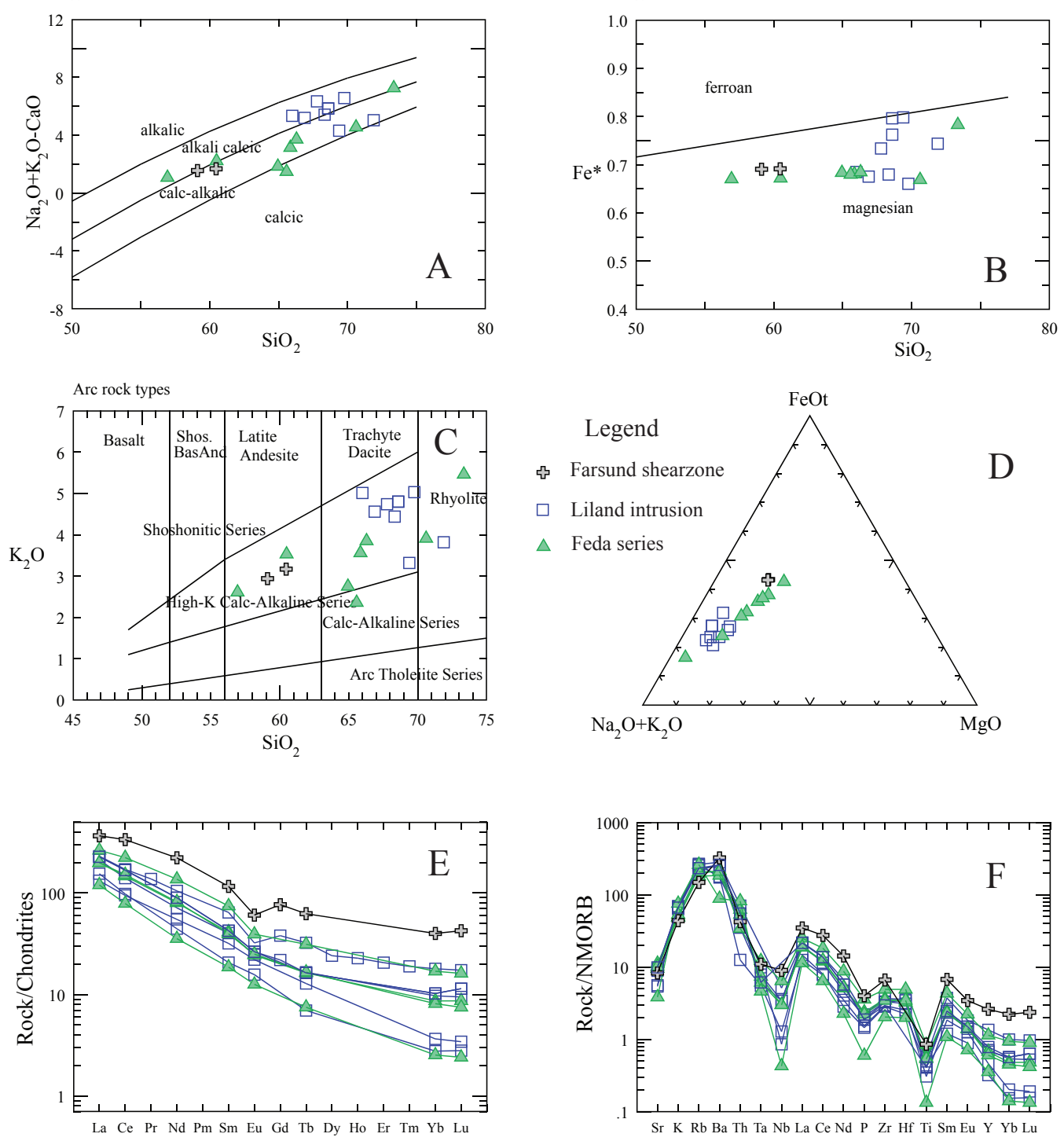

Figure 6. Augen gneiss compositions from the Farsund Shear Zone compared to the Liland intrusion and to selected samples of the Feda suite (data from Bingen, 1989; Bingen et al., 1993). A and B: MALI and Fe* vs. SiO of Frost et al. (2001); C: $\mathrm{K}_{2} \mathrm{O}$ vs. $\mathrm{SiO}_{2}$ of Peccerillo \& Taylor (1976); D: $\mathrm{Na}_{2} \mathrm{O}+\mathrm{K}_{2} \mathrm{O}-\mathrm{FeOt}-\mathrm{MgO}$ diagram; E: chondrite-normalised REE compositions, normalising values after Sun \& MCDonough (1989); F: NMORB normalised spidergrams, normalising values after Sun \& McDonough (1989).

\section{Granitoids}

\section{Charnockite}

Several occurrences of charnockitic rocks are found in the FSZ and in the Flikka banded gneiss. They include a small homogeneous body (Breimyrknuten granite: 81.24, 81.35.4), an offshoot in the Apophysis (81.12.18), thick (decametric) layers $(82.14,81.46)$, and thin (dm-thick) layers (89-57, 89-58). The Breimyrknutan granite (Fig. 2) was mapped and described by Duchesne et al. (1987) as a small body of charnockite (hypersthene granite) showing intrusive contacts against the banded gneiss unit. It is a massive, unfoliated (except in a few places), coarse-grained rock. The offshoot 81.12.18 (Trolldalen) is interpreted as resulting from a back-veining process. In agreement with the definition of Streckeisen $(1974,1976)$, the rocks contain orthopyroxene. They belong to the high-K calc-alkaline series (Fig. 7A) and are ferroan (Fig. 7D). Compared to granites, their composition is characterised by a relatively low $\mathrm{SiO}_{2}$ content (63-70\%) and a high content in mafic elements (Fig. 7B) with high FeOt (Fig. 7E) and TiO2 (Fig. 7F). The Th is very low (Fig. 7G) and the Rb is low (Fig. 7J). The REE are moderately fractionated (Fig. 8A) with $[\mathrm{La} / \mathrm{Yb}]_{\mathrm{N}}<10$ and Eu/Eu* c. 1. 

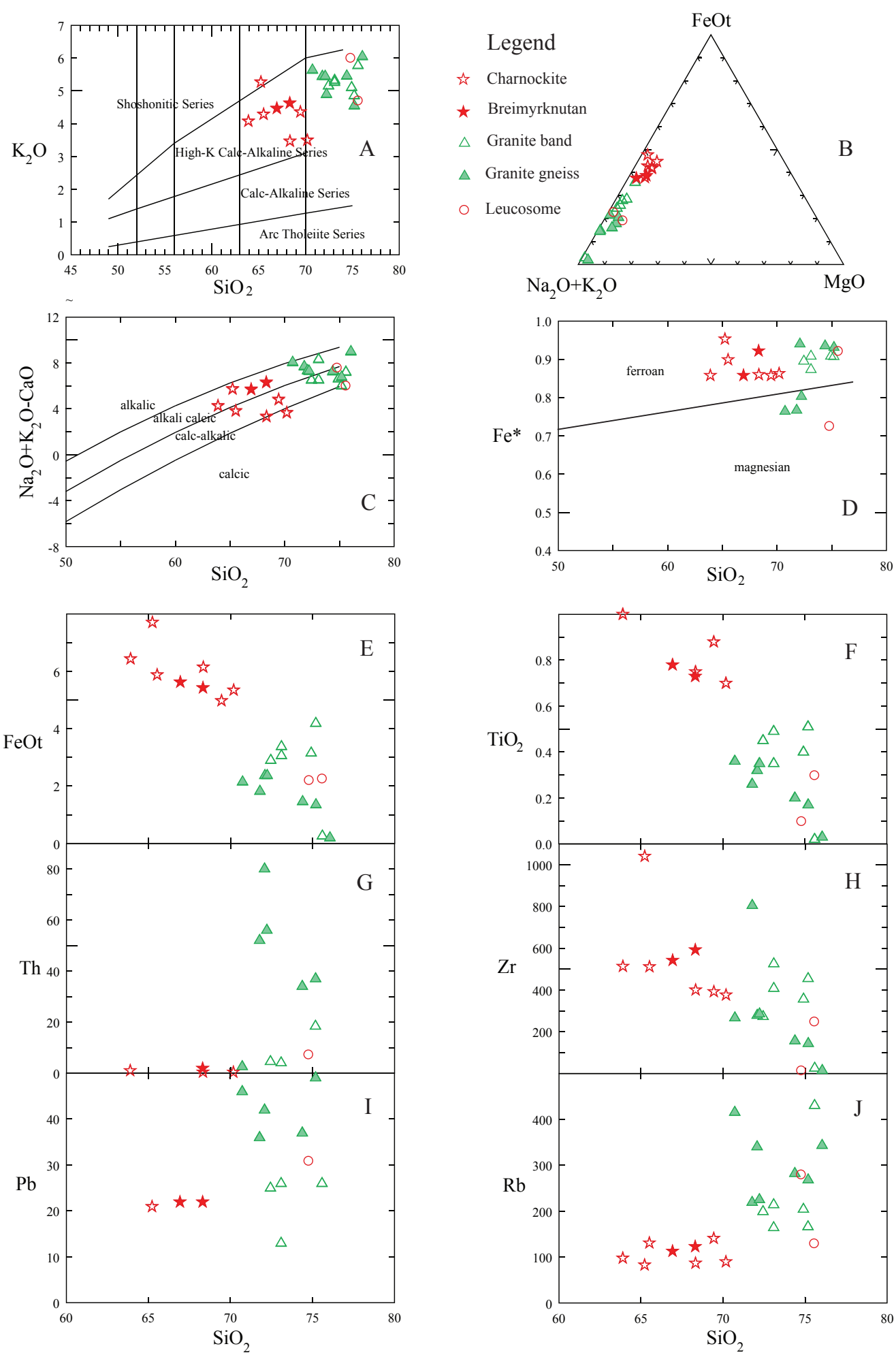

Figure 7. Granitoids compositions. A: $\mathrm{K}_{2} \mathrm{O}$ vs. $\mathrm{SiO}_{2}$ (Peccerillo \& Taylor, 1976); B: $\mathrm{Na}_{2} \mathrm{O}+\mathrm{K}_{2} \mathrm{O}-\mathrm{FeOt}-\mathrm{MgO}$ diagram; C and D: MALI and $\mathrm{Fe}^{*}$ vs. $\mathrm{SiO}_{2}$ (Frost et al., 2001); E to J: Harker diagrams of significant elements. 

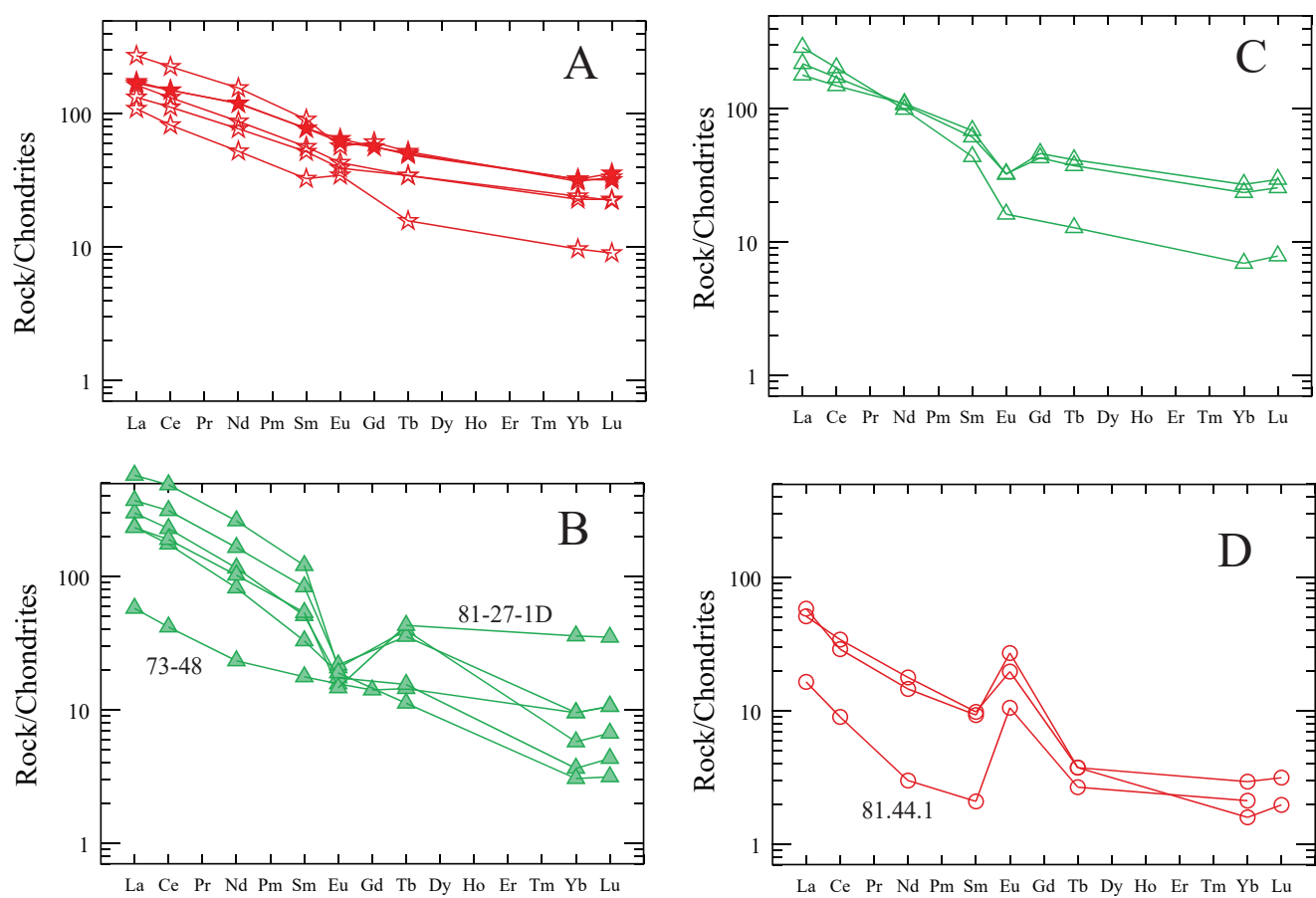

Figure 8. Chondrite-normalised REE distributions. A: Charnockitic rocks; B: Granite gneisses; C: Granite layers; D: leucosomes. Symbols as in Figure 7.

\section{Granitoids}

Several types of granitoids can be distinguished on a geochemical basis. Firstly, granite gneisses; secondly, granitoid layers in the banded gneisses which can be subdivided into granite (s.s.) and leucosome layers. All types belong to the high-K calc-alkalic series (except for sample 89-75 which is calc-alkaline) (Fig. 7A) but the granites are exclusively ferroan, the granite gneiss and the leucosome layers being magnesian to ferroan (Fig. 7D). Compared to the granite layers, most granite gneisses are richer in Th (Fig. 7G), Pb (Fig. 7l) and Rb (Fig. 7J) and lower in FeOt, $\mathrm{TiO}_{2}$ (Fig. 7E, F) and $\mathrm{Zr}$ (Fig. 7H). The REE distributions show high contents, high $[\mathrm{La} / \mathrm{Yb}]_{N}$ ratios and high Eu negative anomalies in granite gneiss (except the intriguing 73-48) (Fig. 8B), slightly lower REE contents and La/Yb ratios and small Eu anomalies in granitic layers (Fig. $8 \mathrm{C}$ ), and the lowermost REE contents with large positive Eu anomalies in leucosome layers (Fig. 8D). Sample 81.27.1D (Fig. 8B) is a granite gneiss with a high HREE content which resembles the profile of a granite band but its high $\mathrm{Pb}$ and Th concentrations preclude its belonging to this group. Two hololeucocratic granites (samples 81.27.2 and 83.22.2C) are very low in $\mathrm{Fe}, \mathrm{Ti}$ and $\mathrm{Zr}$ (Fig. 7).

\section{Tracing the origin of the various rock types}

\section{Metabasites}

The jotunitic metabasites can be related to the RAP magmatism. They have indeed strong similarities to the jotunite compositions (Duchesne et al., 1989; Vander Auwera et al., 1998, 2011) that are intimately linked to the AMC plutonism, irrespective of whether they are interpreted as parental magmas (e.g., Duchesne et al., 1999; Liégeois et al., 2002) or residual liquids (Bybee et al., 2014). The influence of the metamorphic phases on metabasite compositions has been assessed by Vander Auwera (1993) who has shown that $\mathrm{P}, \mathrm{Ti}$ and $\mathrm{Al}$ are inert components in the transition from amphibolite facies to granulite facies. Thus, $\mathrm{P} / \mathrm{Al}$ and $\mathrm{Ti} / \mathrm{Al}$ ratios are not modified in the process and the high $\mathrm{P}_{2} \mathrm{O}_{5}$ and $\mathrm{TiO}_{2}$ values have not been significantly modified and thus reflect original characteristics. It is worth noting that a jotunite 
(sample 84-24 from Moi) typically shows the development of a hypersthene rim at the contact with the neighbouring felsic band. As shown by Vander Auwera (1993), the rim development took place after the folding of the banded gneisses which implies the early intrusion of the jotunitic magma in the envelope prior to the M2 contact metamorphism and its associated deformation in the shear zones. This jotunite could be contemporaneous with the early phase of the RAP formation and be older than $930 \mathrm{Ma}$.

The other types of metabasites are more difficult to interpret. The classical view that these amphibolites could have a metasedimentary origin can be readily rejected because there are no associated carbonate rocks in the banded gneisses. Thus, the amphibolite protoliths must have an igneous origin and could have been affected to various degrees by migmatisation processes, indicated in particular by a sharp decrease of $\mathrm{F}$ and an increase of $\mathrm{Nb}$ and Ta when passing into granulite-facies conditions (Vander Auwera,1993). In addition, this author concluded that the REE distributions are not significantly affected by metasomatic processes and must reflect geochemical properties of the protolith. The flat REE distributions of the amphibole metabasites and the relatively low $[\mathrm{La} / \mathrm{Yb}]_{N}$ ratios of the biotite-bearing amphibolites and two-pyroxene norites (Fig. 5) are consistent with an oceanic origin, a feature which is corroborated by the Ti-V diagram of Shervais (1982) and the Ti-Zr diagram of Pearce \& Cann (1973) (Fig. 9).
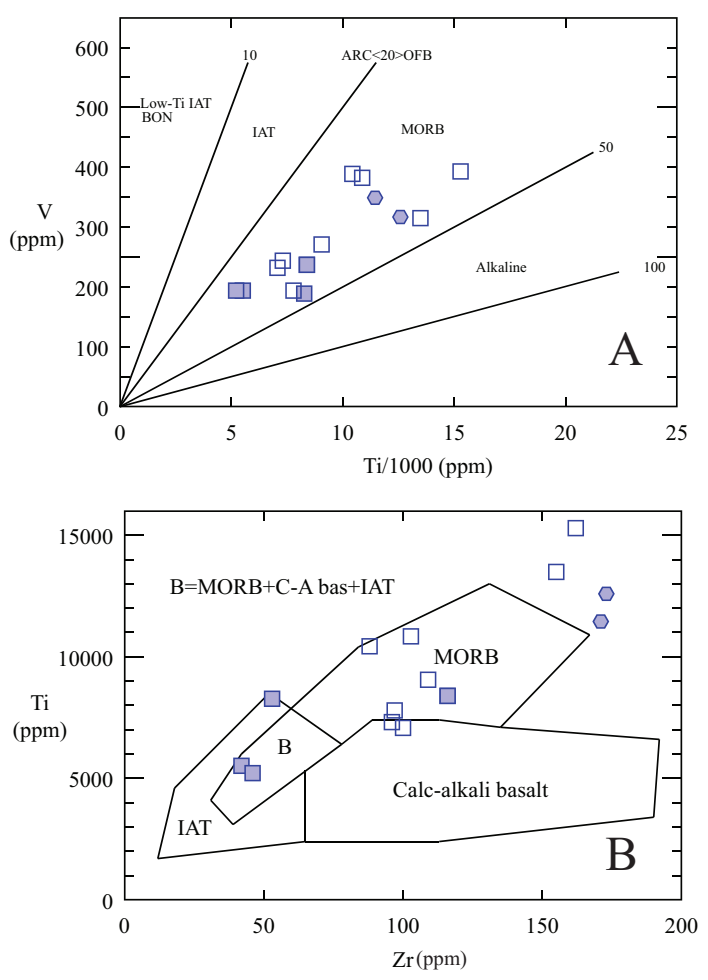

Figure 9. Trace element contents of metabasites with $\mathrm{CaO}+\mathrm{MgO}$ in the 12 to $20 \%$ range and tectonic environment. A: $V$ vs. Ti/1000 diagram of Shervais (1982). B: Ti vs. Zr diagram of Pearce \& Cann (1973). Abbreviations: IAT - Island-arc tholeiite; MORB Mid Ocean Ridge Basalt; C-A bas - arc basalt.

\section{The metasedimentary character of the kinzigitic gneiss}

The major element compositions of the kinzigitic gneiss and its migmatitic leucosome and melanosome, projected in the Eskola triangles (Eskola, 1920), show that the homogeneous sample 81.12.1A was initially a pelitic sediment essentially made up of quartz, chlorite and muscovite (Fig. 10). The pelitic character is corroborated by the REE distribution compared to the Post-Archaean Argillaceous Shales (PAAS) (Taylor \& McLennan, 1985) (Fig. 11). It is also very close to the upper continental crust composition of Taylor \& McLennan (1985) except for an intriguing low Sr content (Fig. 11C). It is worth noting that the leucosome composition is particularly depleted in HREE and shows a positive Eu anomaly (Fig. 11B), features characteristic of migmatitic leucosomes (see below). The melanosome is enriched in HREE and complements the leucosome composition. 


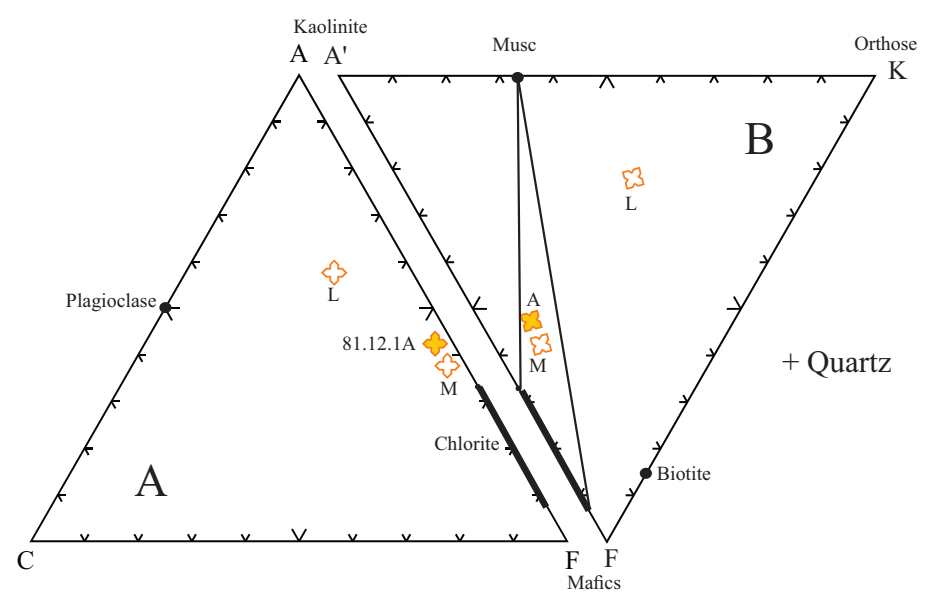

Figure 10. Kinzigitic gneiss composition (mol\%) projected in the Eskola triangles associating minerals and whole-rock compositions (Eskola, 1920). A: Triangle ACF (mol. \%) with $A=\left(\mathrm{Al}_{2} \mathrm{O}_{3}\right)-\left(\mathrm{K}_{2} \mathrm{O}\right)-\left(\mathrm{Na} \mathrm{O}_{2} \mathrm{O}\right), \mathrm{C}=(\mathrm{CaO}), \mathrm{F}=(\mathrm{FeOt})+(\mathrm{MgO})$. B: Triangle $A^{\prime} K F\left(\mathrm{~mol}\right.$. \%) with $A^{\prime}=\left(\mathrm{Al}_{2} \mathrm{O}_{3}\right)-\left(\mathrm{K}_{2} \mathrm{O}\right)-\left(\mathrm{Na}_{2} \mathrm{O}\right)-(\mathrm{CaO}), \mathrm{K}=\left(\mathrm{K}_{2} \mathrm{O}\right), \mathrm{F}=(\mathrm{FeOt})+(\mathrm{MgO})$. Abbreviations: $\mathrm{M}-$ melanosome 81.12.1BM; L - Leucosome 81.12.1BL; A - homogeneous sample 81.12.1A.

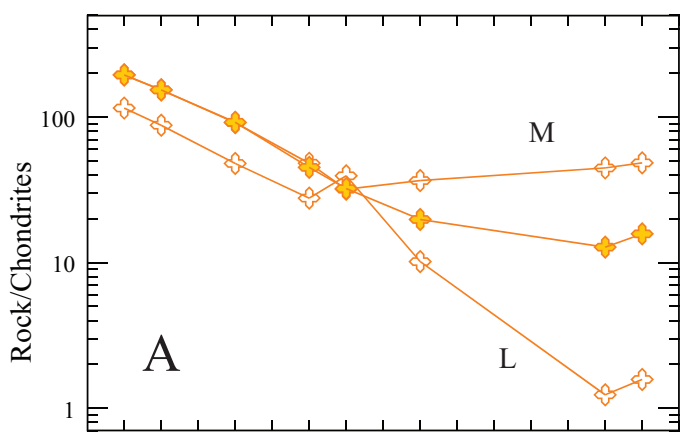

$\mathrm{La} \mathrm{Ce}$ Pr Nd Pm Sm Eu Gd Tb Dy Ho Er Tm Yb Lu
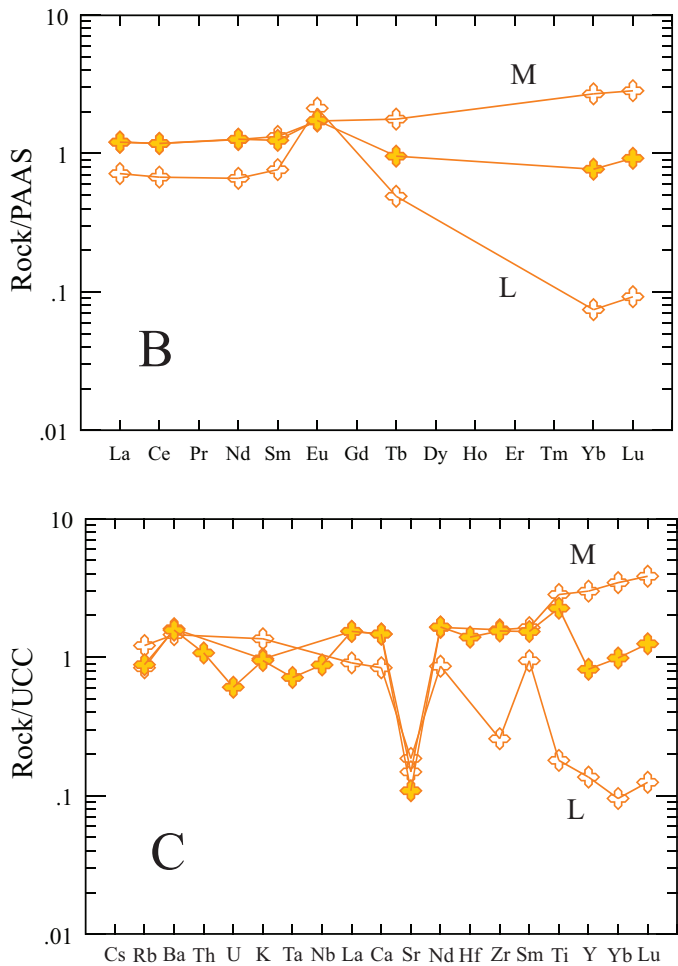

Figure 11. Trace element compositions of kinzigitic gneisses. A: Chondrite-normalised REE compositions (normalising values after Sun \& McDonough, 1989). B: PAAS-normalised REE compositions (normalising values after Taylor \& McLennan, 1985). C: Upper Continental Crust (UCC) normalised trace elements (normalising values after Taylor \& McLennan, 1985). Abbreviations: M - melanosome 81.12.1BM; L - Leucosome 81.12.1BL. 


\section{Migmatitic leucosomes}

Some of the granite layers in the banded gneiss are interpreted as migmatitic leucosome essentially on the basis of their REE distributions (Fig. 8D) that show low REE concentrations and a clear positive Eu anomaly. The same is also observed in sample 81.12.1BL (Fig. 11B), the leucosome associated with the kinzigitic gneiss 81.12.1A. Such REE profiles are commonly observed in migmatitic rocks (Barbey et al., 1989; Vander Auwera, 1993; Duchesne \& Wilmart, 1997), and are usually interpreted as resulting from selective anatexis of feldspar and quartz, with heavy REE retained in the residue by an accessory mineral such as zircon and common mafic minerals. A detailed discussion is outside the framework of the present paper.

\section{Charnockites}

Two possible origins of charnockitic compositions have been proposed, and they both seem to be compatible with available major and trace element data. On the basis of experimental data in a pure $\mathrm{CO}_{2}$ gas phase, Wendlandt (1981) has argued that charnockitic melts could be produced by anatexis. Field relationships were supporting this mechanism for the Breimyrknutan granite (Duchesne et al., 1987; Duchesne et al., 2001).

Another process for the formation of charnockites has been documented in the neighbouring Farsund intrusion (Vander Auwera et al., 2014a). A differentiation series starting at around $65 \% \mathrm{SiO}_{2}$ (a quartz monzonitic composition $\mathrm{AD011}$ ) and extending up to $72 \% \mathrm{SiO}_{2}$ has been defined. It can also be explained by classical concepts of plutonic crystallisation. The chemical variation trends are shown in Fig. 12 and compared to the compositions of our samples in the FSZ. These trends globally mimic our compositions if natural variations in compositions are considered, namely in the Breimyrknutan body and in two samples, 89-57g1 and 89-57g2, from the same layer.

\section{Comparison with the Sirdal magmatic belt}

In the high-grade gneiss domain of South Norway, the banded gneiss formations have been intruded by plutons of the Sirdal magmatic belt (SMB) and are thus older than 1070-1020 Ma (Coint et al., 2015; Slagstad et al., 2018). Could some magmatic products from the SMB have intruded the FSZ? The occurrence of the Liland augen gneiss, dated at c. $1051 \mathrm{Ma}$ (Bingen \& van Breemen, 1998), that crops out close to and parallel to the FSZ (Fig. 1) is evidence that the SMB intrusive process can inject magma batches at some distance $(10-15 \mathrm{~km}$ ) outside the main belt. It is therefore plausible (and the simplest interpretation) that augen gneisses with compositions analogous to the Feda suite could also represent SMB offshoots emplaced in the 1070-1020 Ma interval.

On a more general basis, it is worth comparing our granitoids to the SMB database of Slagstad et al. (2013) (Fig. 13). It turns out that charnockites with their high contents in FeOt (Fig. 13A) and $\mathrm{TiO}_{2}$ (Fig. 13B) together with very low Th (Fig. 13C) are not found in the SMB. Many SMB granitoids are rich in Th, $\mathrm{Pb}$ and $\mathrm{Rb}$, a feature characteristic of our granite gneiss unit, although samples 72.158 and 81.15 have $[\mathrm{La} / \mathrm{Yb}]_{\mathrm{N}}$ ratios much higher than any SMB rocks. More samples are needed to constrain the origin of our granite gneisses but, globally, as for the $\mathrm{SMB}$, an arc origin cannot be precluded considering their high-K calc-alkaline character. Moreover, Figs. 13A, B, D show that our granite layers with their high $\mathrm{FeOt}, \mathrm{TiO}_{2}$ and $\mathrm{Zr}$ contents have very few equivalents in the SMB. Their formation and intrusion during the SMB event is thus highly unlikely. We show below that they are possibly related to the older Suldal Arc. 


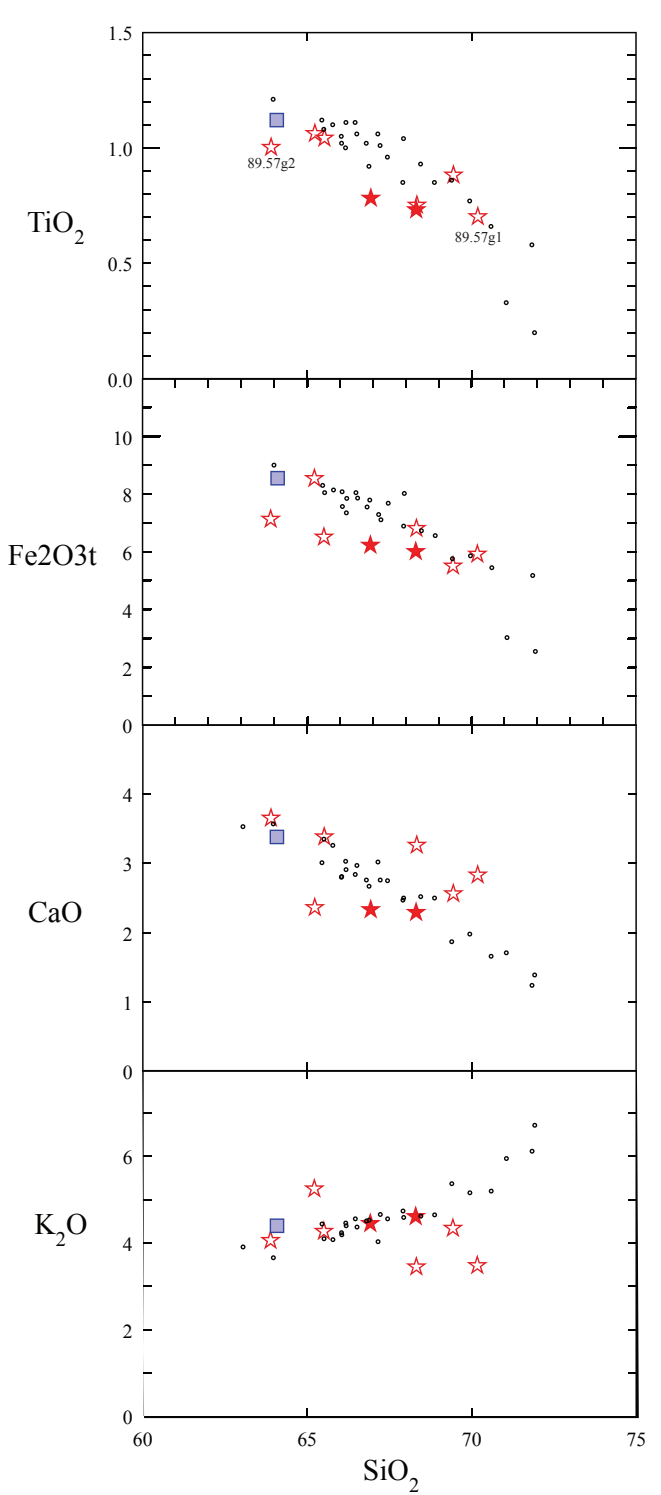

$\star$ Breimyrknutan is Other charnockites

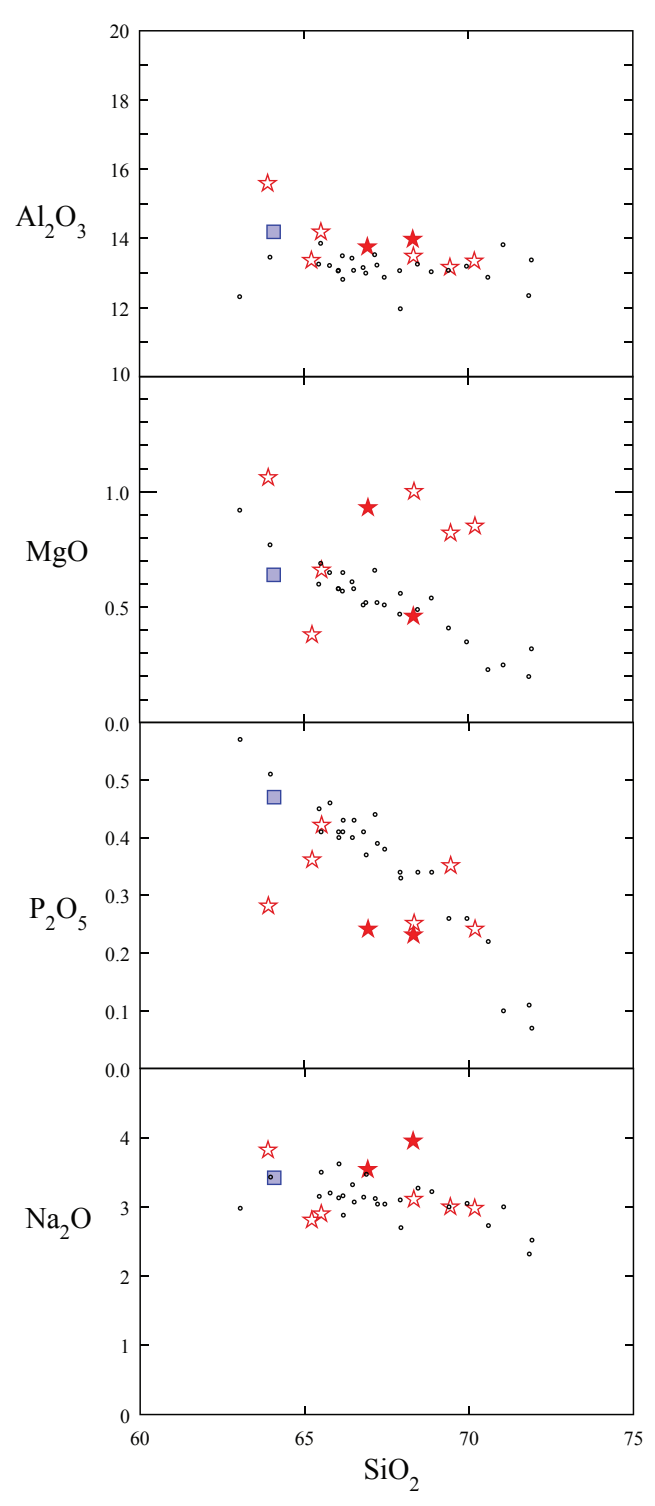

$\square$ Parental magma AD011 • Charnockitic LLD

Figure 12. Harker diagrams comparing the charnockitic rocks (Breimyrknutan intrusion and charnockitic layers in banded gneiss) with the charnockitic chemical variation trends (LLD) and assumed parental magma composition AD011 of the Farsund intrusion (data from Vander Auwera et al., 2014a).

\section{Relationships with the Suldal arc lithologies}

Could the banded gneisses in the study area have any relationships with the older c. 1520-1480 Ma Suldal arc lithologies that outcrop in the northwestern part of the Rogaland Hardangervidda sector (Roberts et al., 2013)? In the Suldal arc, the major and trace element compositions of grey gneisses ranging from 50 to $78 \% \mathrm{SiO}_{2}$ and granitoids from 65 to $76 \% \mathrm{SiO}_{2}$ have been reported by Roberts et al. (2013). These two series of rocks and our granite gneisses and granite layers are high-K calc-alkaline and may thus have been formed in the same arc context. There are, however, significant differences when trace elements are considered. We compare granite gneissses and the granite layers in the banded gneisses to the Suldal granitoids and grey gneisses $>70 \% \mathrm{SiO}_{2}$ in Fig. 14. It appears that our granite gneisses (with typical high Th, $\mathrm{Pb}, \mathrm{Rb}$ and $[\mathrm{La} / \mathrm{Yb}]_{N}$ ratios; Fig.14A, B, C, D) are not represented in the Suldal arc while our granitic layers cannot be distinguished from the Suldal lithologies (Fig. 14A, B, C, D). Thus, we cannot preclude that our granite layers could have been formed by the same process and at the same time as the age of the Suldal arc. 


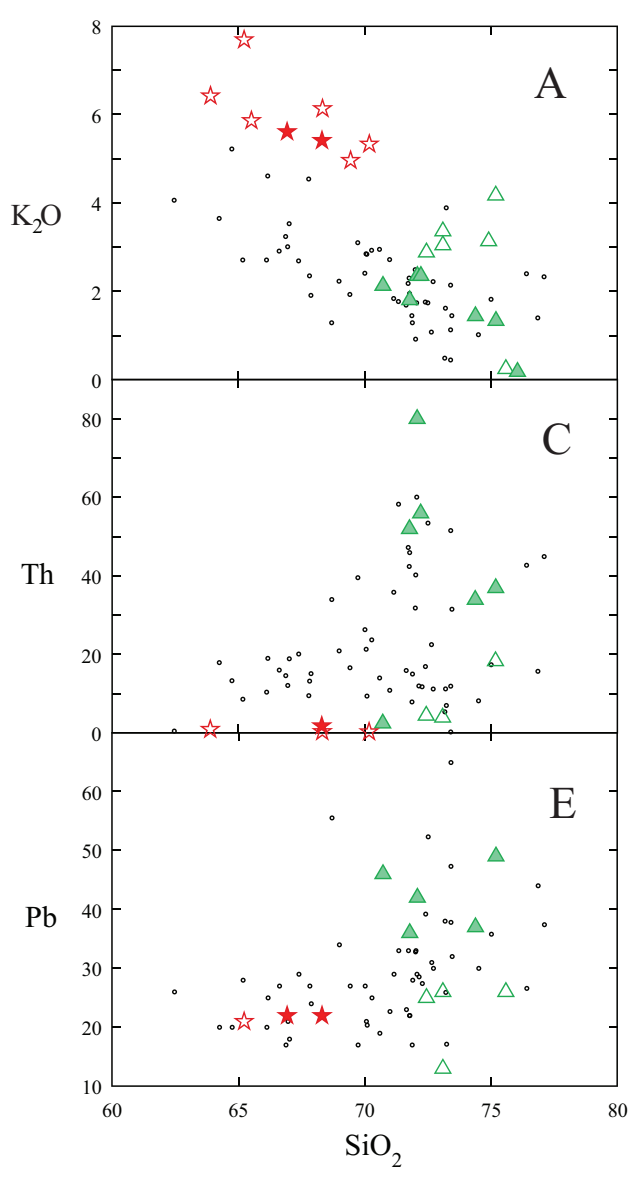

Granite gneiss

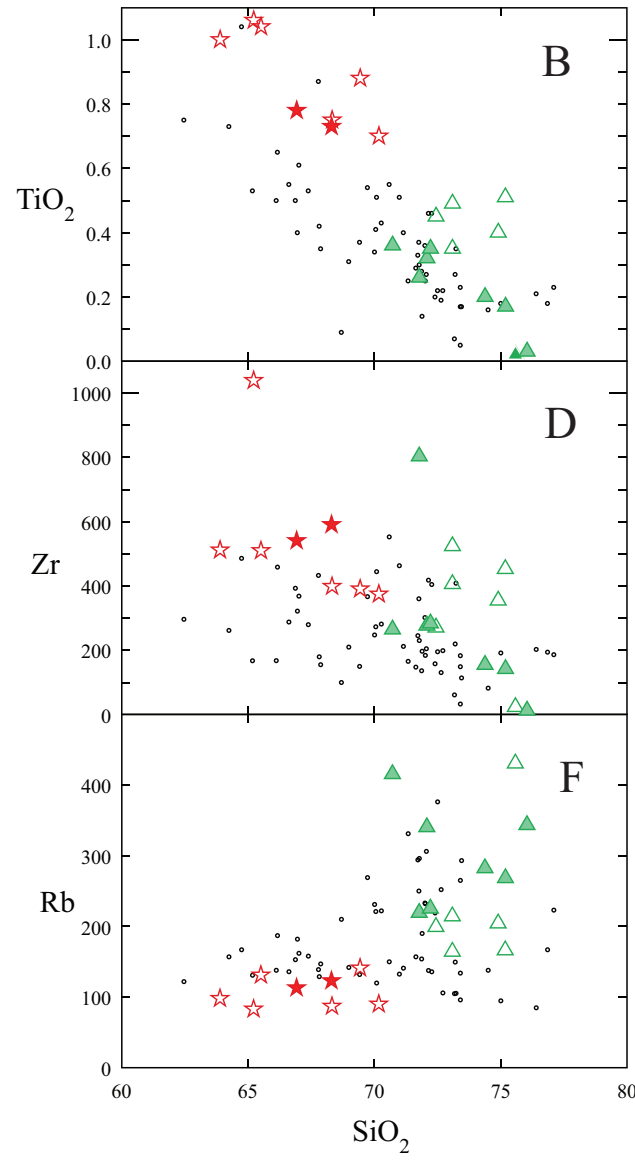

* Charnockite $\star$ Breimyrknutan . SMB rocks

Figure 13. Harker diagrams comparing the granite gneisses, the granite layers and the charnockitic rocks (Breimyrknutan intrusion and charnockitic layers) to the Sirdal magmatic belt (SMB) rocks (data from Slagstad et al., 2013).

Compared to the less evolved Suldal grey gneisses (Fig. 15), our amphibolite metabasites are lower in $\mathrm{SiO}_{2}$ (Fig. 15A) and $\mathrm{K}_{2} \mathrm{O}$ (Fig. 15C), and higher in FeOt (Fig. 15A). Most biotite-bearing and the 2-pyroxene metabasites have higher $\mathrm{TiO}_{2}$ contents than the grey gneisses (Fig. 15B). The REE distributions in all metabasites (Fig. 15E) show lower $[\mathrm{La} / \mathrm{Yb}]_{N}$ ratios than in most of the grey gneisses (Fig. 15D, E).

We can speculate that our granite gneiss may have formed in an arc context but with a source or evolution different from that of the Suldal arc. Our metabasites with oceanic characteristics could belong to altered oceanic material (with overlying sediments, the kinzigitic gneiss) that, in Roberts' model, were accreted to a pre-existing continental margin and that were in part underthrust to the magma generation zone of the Suldal arc. Finally, the only vestige of the c. 1500 Ma Suldal arc in the south of the Hardangervidda-Rogaland sector would be the granite layers in the banded gneisses. 

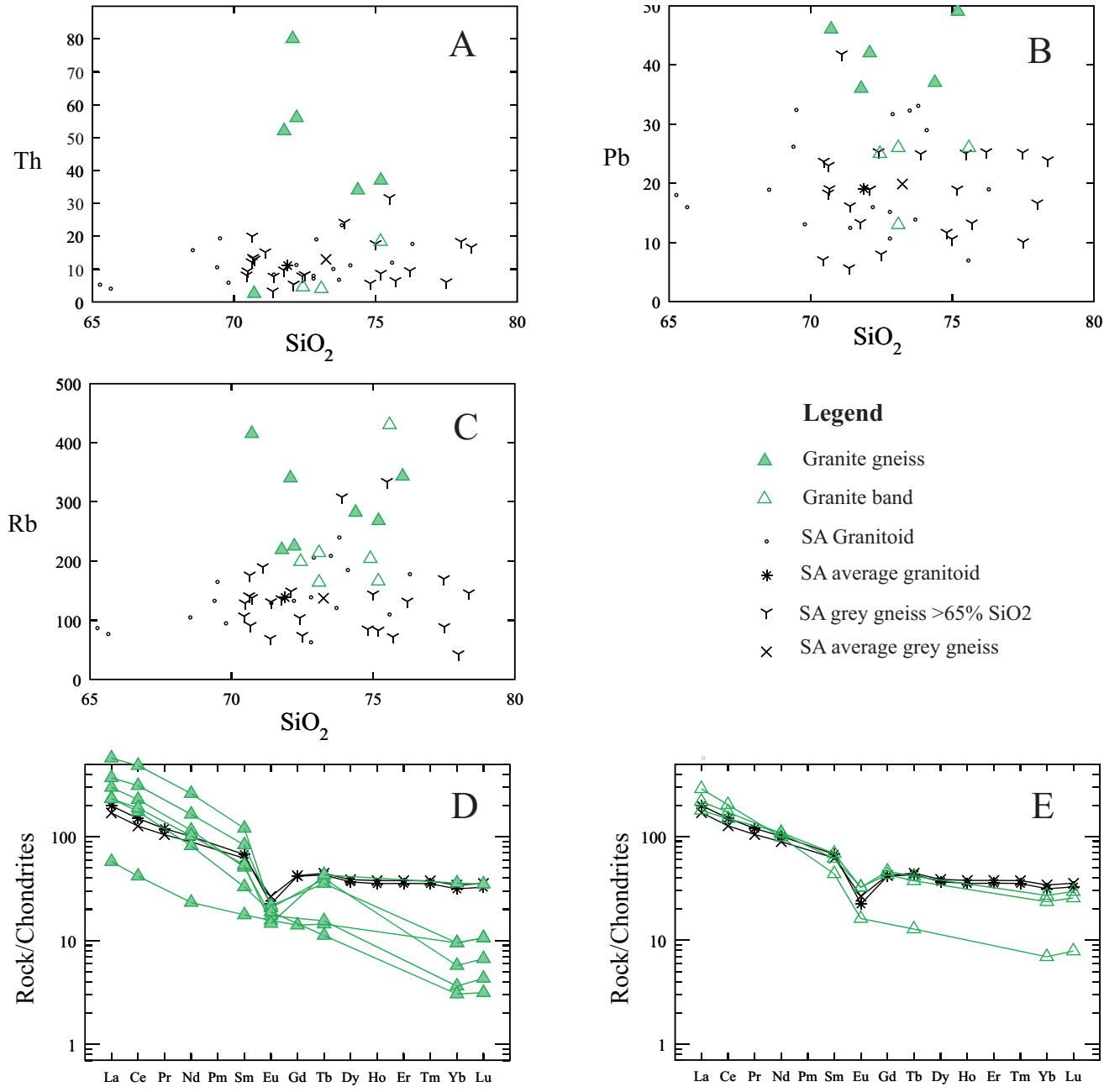
Suldal arc (SA) granitoids and grey gneisses (> 65\% SiO2) (data from Roberts et al., 2013).

\section{Timing of the magmatic events in the shear zone}

The FSZ was particularly active during the waning stages of the Sveconorwegian orogeny with the intrusion of anorthosite and related rocks. Anorthosite massifs are commonly related to major lithospheric structures (Emslie et al., 1994; Scoates \& Chamberlain, 1997; Wiszniewska et al., 2002; Bogdanova et al., 2004; Shumlyanskyy et al., 2017). On a large scale it has been suggested that the RAP intruded along a lithospheric-scale weakness zone (Duchesne et al., 1999) detected through deep seismic data (Andersson et al., 1996). The eastern-most part of this structure is now represented by the FSZ (Bolle et al., 2010).

The Hidra anorthosite massif dated at $932 \pm 9$ Ma (Vander Auwera et al., 2011) intruded as a wedge in the FSZ. It is the youngest intrusion in the area as evidenced by its undeformed structure. The charnockitic part of the Farsund intrusion at $931 \pm 2$ Ma has been emplaced mainly through the same channel. This age is within errors similar to the Hidra intrusion but blastomylonitic structures in the Farsund intrusion close to the contact with the Hidra intrusion clearly point to a slightly older age than this massif.

The Breimyrknutan charnockite and possibly the charnockitic layers were formed and emplaced contemporaneously with the Hidra body and with the Apophysis. The heat flow from both intrusions provided the high temperatures required for anatexis. 

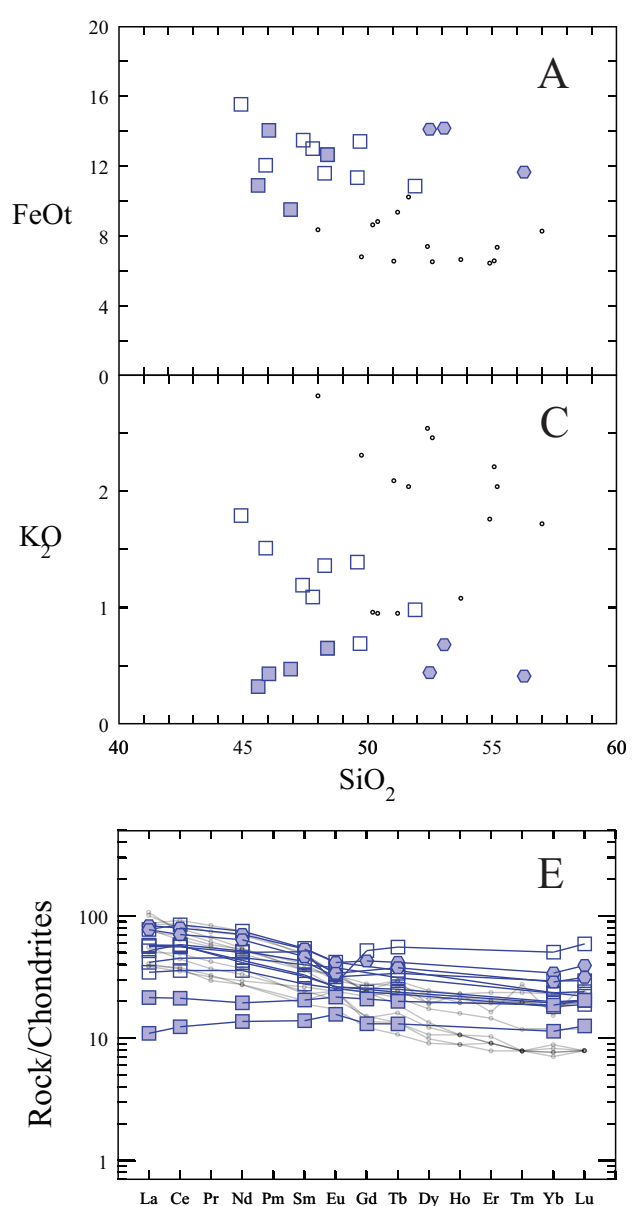

Figure 15. Harker and chondrite-normalised REE diagrams comparing metabasites with the Suldal arc grey gneisses $\left(<57 \% \mathrm{SiO}_{2}\right.$ ) (data from Roberts et al., 2013).

We suggest that the jotunite metabasite intrusions have taken place over a large time interval. They can be related to the emplacement of the RAP and more precisely either to the main magmatic stage at 933-929 Ma (Schärer et al., 1996; Vander Auwera et al., 2011) or to a later pulse of jotunitic magma in dykes at 920-916 Ma (Vander Auwera et al., 2011). Undeformed reaction rims between jotunitic and granitic layers at Moi (sample 84-24) (Vander Auwera, 1993) point to the early occurrence of jotunite in the envelope of the RAP prior to the deformation linked to the anorthosite emplacement. Such jotunite could thus be coeval with the very early stage of the HAOM (High Aluminum Orthopyroxene Megacryst) formation dated at $1041 \pm 17 \mathrm{Ma}$ (Bybee et al., 2014; Vander Auwera et al., 2014b).

Do we have evidence of magmatic events in the FSZ during the main Sveconorwegian orogeny (1070 $-1020 \mathrm{Ma})$ ? In the building up of the Sirdal magmatic belt, the banded gneiss units, coined by Falkum (1982), were described as "N-S-oriented zones rich in xenoliths" or as "screens of metamorphosed and deformed rocks" by Coint et al. (2015). Slagstad et al. (2018) show a geological map of the SMB on which kilometre-wide screens can be followed for several tens of kilometres. The xenoliths comprise a large variety of rocks from metabasites to granitoidic grey gneisses in various stages of migmatisation. The banded gneiss units of Falkum were intruded by the SMB products and are thus at least partly older than the 1070-1010 Ma SMB.

The augen gneisses in the FSZ have calc-alkaline affinities comparable to the Feda trend and could have intruded the banded gneiss unit at the time of the SMB magmatism in the same way as the $1051 \mathrm{Ma}$ Liland augen gneiss intrusion (Bingen, 1989; Bingen \& van Breemen, 1998) at some distance from the main magmatic belt. However, they are geochemically distinct from the Liland intrusion but analogous to the Feda augen gneiss. 
Finally, we have some indications that the FSZ could have integrated lithologies as old as $1500 \mathrm{Ma}$. Our granite layers are compositionally similar to the Suldal arc grey gneisses and granitoids. In addition, our amphibolite- and biotite-bearing metabasites and our metapelitic rocks could represent fragments of an oceanic crust and its sedimentary cover cotemporaneous with or even older than the c. $1500 \mathrm{Ma}$ Suldal arc.

\section{Conclusions}

The FSZ has been intruded by various types of magmatic rocks, besides the anorthosite massifs and the BKSK layered intrusion and more specifically in the studied area by the Hidra anorthosite and the Farsund massif. Charnockitic layers or bodies were possibly derived by local anatexis, such as the Breimyrknutan granite, or derived from fractionation of a quartz monzonitic magma, contemporaneous with the RAP magmatism in the 933-916 Ma interval. Jotunites were also emplaced during this event or slightly before. Augen gneisses similar to the Feda gneiss are coeval with the 1070-1010 Ma SMB. It cannot be precluded that granitic banded gneisses, other than migmatitic leucosomes, could have been produced by the same arc-related magmatism as the 1500 Ma Suldal arc. Metabasites with oceanic signatures may represent fragments of the ocean crust involved in the Suldal arc subduction and the kinzigitic gneisses could be relics of sedimentary material deposited on that crust. The shear zone has thus been active during more than $500 \mathrm{Myr}$ and has tapped a variety of sources. It is a major component of the Sveconorwegian orogen.

Acknowledgements. The help of Edith Wilmart with the fieldwork and the petrographic study is particularly acknowledged. The paper has benefited from discussions with Olivier Bolle. Bernard Bingen and Øystein Nordgulen are specially thanked for their constructive reviews.

\section{References}

Andersson, M., Lie, J.E. \& Husebye, E.S. 1996: Tectonic setting of post-orogenic granites within SW Fennoscandia based on deep seismic and gravity data. Terra Nova 8, 558-566. https://doi.org/10.1111/j.1365-3121.1996.tb00785.x

Annen, C., Blundy, J. \& Sparks, R. 2006: The genesis of intermediate and silicic magmas in deep crustal hot zones. Journal of Petrology 47, 505-539. https://doi.org/10.1093/petrology/egi084

Barbey, P., Bertrand, J.M., Angoua, S. \& Dautel, D. 1989: Petrology and U/Pb geochronology of the Telohat migmatites, Aleksod, Central Hoggar, Algeria. Contributions to Mineralogy and Petrology 101, 207-219. https://doi.org/10.1007/BF00375307

Barnichon, J.-D., Havenith, H., Hoffer, B., Charlier, R., Jongmans, D. \& Duchesne, J.C. 1999: The deformation of the Egersund Ogna massif, South Norway: finite element modelling of diapirism. Tectonophysics 303, 109-130. https://doi.org/10.1016/S0040-1951(98)00247-9

Bingen, B. 1989: Geochemistry of Sveconorwegian augen gneisses from SW Norway at the amphibolite-granulite faciess transition. Norsk Geologisk Tidsskrift 69, 177-189. 
Bingen, B. \& van Breemen, O. 1998: Tectonic regimes and terrane boundaries in the high-grade Sveconorwegian belt of SW Norway, inferred from U-Pb zircon geochronology and geochemical signature of augen gneiss suites. Journal of the Geological Society of London 155, $143-154$. https://doi.org/10.1144/gsjgs.155.1.0143

Bingen, B., Demaiffe, D., Hertogen, J., Weis, D. \& Michot, J. 1993: K-rich calc-alkaline augen gneisses of Grenvillian age in SW Norway: mingling of mantle-derived and crustal components. Journal of Geology 101, 763-768. https://doi.org/10.1086/648273

Bingen, B., Stein, H.J., Bogaerts, M., Bolle, O. \& Mansfeld, J. 2006: Molybdenite Re-Os dating constrains gravitational collapse of the Sveconorwegian orogen, SW Scandinavia. Lithos 87, 328-346.

https://doi.org/10.1016/j.lithos.2005.06.017

Bingen, B., Corfu, F., Stein, H.J. \& Whitehouse, M.J. 2015: U-Pb geochronology of the syn-orogenic Knaben molybdenum deposits, Sveconorwegian orogen, Norway. Geological Magazine 152, 537-556. https://doi.org/10.1017/S001675681400048X

Bogdanova, S., Pashkevich, I.K., Buryanov, V.B., Makarenko, I.V., Orlyuk, M.I., Skobelev, V.M., Starostenko, V.I. \& Legostaeva, O.V. 2004: The 1.80-1.74 Ga anorthosite-rapakivi granite Korosten Pluton in the Ukrainian Shield: a 3-D geophysical reconstruction of deep structure. Tectonophysics 381, 5-27. https://doi.org/10.1016/j.tecto.2003.10.023

Bolle, O., Diot, H., Liégeois, J.-P. \& Vander Auwera, J. 2010: The Farsund intrusion (SW Norway): A marker of late-Sveconorwegian (Grenvillian) tectonism along a newly defined major shear zone. Journal of Structural Geology 32, 1500-1518. https://doi.org/10.1016/j.jsg.2010.04.003

Bybee, G.M., Ashwal, L.D., Shirey, S., Horan, M., Mock, T. \& Andersen, T. 2014: Pyroxene megacrysts in Proterozoic anorthosites: Implications for tectonic setting, magma source and magmatic processes at the Moho. Earth and Planetary Science Letters 389, 74-85. https://doi.org/10.1016/j.epsl.2013.12.015

Charlier, B., Duchesne, J.C., Vander Auwera, J., Storme, J.-Y., Maquil, R. \& Longhi, J. 2010: Polybaric fractional crystallization of high-alumina basalt parental magmas in the Egersund-Ogna massiftype anorthosite (Rogaland, SW Norway) constrained by plagioclase and high-alumina orthopyroxene megacrysts. Journal of Petrology 51, 2547-2570. https://doi.org/10.1093/petrology/egq066

Coint, N., Slagstad, T., Roberts, N.M.W., Marker, M., Røhr, T.S. \& Sørensen, B.E. 2015: The Late Mesoproterozoic Sirdal Magmatic Belt, SW Norway: relationships between magmatism and metamorphism and implications for Sveconorwegian orogenesis. Precambrian Research 265, 57-77. https://doi.org/10.1016/j.precamres.2015.05.002

Demaiffe, D. \& Hertogen, J. 1981: Rare earth element geochemistry and strontium isotopic composition of a massif-type anorthositic-charnockitic body: the Hidra massif (Rogaland, SW. Norway). Geochimica Cosmochimica Acta 45, 1545-1561. https://doi.org/10.1016/0016-7037(81)90284-2

Demaiffe, D., Duchesne, J.C., Michot, J. \& Pasteels, P. 1973: Le massif anorthosito-leuconoritique d'Hidra et son faciès de bordure. Comptes Rendus de l'Académie des Sciences de Paris 277, 14-20.

Drüppel, K., Elsässer, L., Brandt, S. \& Gerdes, A. 2013: Sveconorwegian mid-crustal ultrahightemperature metamorphism in Rogaland, Norway: U-Pb LA-ICP-MS geochronology and pseudosections of sapphirine granulites and associated paragneisses. Journal of Petrology 54, 305-350. https://doi.org/10.1093/petrology/egs070 
Duchesne, J.C. 1984: Massif anorthosites: another partisan review. In: Brown, W.S. (ed.): Feldspars and feldspathoids. Reidel, Dordrecht, pp. 411-433. https://doi.org/10.1007/978-94-015-6929-3_11

Duchesne, J.C. 1990: Origin and evolution of monzonorites related to anorthosites. Schweizerische Mineralogische und Petrographische Mitteilungen 70, 189-198.

Duchesne, J.C. \& Hertogen, J. 1988: Le magma parental du lopolithe de Bjerkreim-Sokndal (Norvège méridionale). Comptes Rendus de l'Académie des Sciences de Paris 306, 45-48.

Duchesne, J.C. \& Wilmart, E. 1997: Igneous charnockites and related rocks from the Bjerkreim-Sokndal layered intrusion (Southwest Norway): a jotunite (hypersthene monzodiorite)-derived A-type granitoid suite. Journal of Petrology 38, 337-369. https://doi.org/10.1093/petroj/38.3.337

Duchesne, J.C. \& Korneliussen, A. 2003: Ilmenite deposits and their geological environment, with special reference to the Rogaland Anorthosite Province, including a geological map at scale 1:75,000 and a CD with a guide to the province, Norges geologiske undersøkelse Special publication 9, 138 pp.

Duchesne, J.-C., Demaiffe, D. \& Wilmart, E. 1987: Fidsel-Vardefjell-Itland: Apophysis, Hidra massif and enveloppe. In: Maijer, C. \& Padget, P. (eds.): The geology of southernmost Norway: an excursion guide. Norges Geologiske Unders $\varnothing$ kelse Special Publication 1, pp. 42-47.

Duchesne, J.C., Wilmart, E., Demaiffe, D. \& Hertogen, J. 1989: Monzonorites from Rogaland (Southwest Norway): a series of rocks coeval but not comagmatic with massif-type anorthosites. Precambrian Research 45, 111-128. https://doi.org/10.1016/0301-9268(89)90034-X

Duchesne, J.C., Liégeois, J.P., Vander Auwera, J. \& Longhi, J. 1999: The crustal tongue melting model and the origin of massive anorthosites. Terra Nova 11, 100-105.

https://doi.org/10.1046/j.1365-3121.1999.00232.x

Duchesne, J.C., Demaiffe, D., Bolle, O., Vander Auwera, J. \& Wilmart, E. 2001: The Rogaland intrusive massifs: eastern part. In: Duchesne, J.C. (ed.): The Rogaland intrusive massifs: an excursion guide. NGU Report 2001.029, pp. 112-127.

Emslie, R.F., Hamilton, M.A. \& Thiérault, R.J. 1994: Petrogenesis of a Mid-Proterozoic Anorthosite Mangerite - Charnockite - Granite (AMCG) complex: isotopic and chemical evidence from the Nain plutonic suite. Journal of Geology 102, 539-558. https://doi.org/10.1086/629697

Eskola, P. 1920: The mineral facies of rocks. Norsk Geologisk Tidsskrift 6, 143-194.

Falkum, T. 1982: Geologisk kart over Norge, berggrunnskart Mandal, 1:250000. Norges Geologiske Undersøkelse.

Falkum, T. 1985: Geotectonic evolution of southern Scandinavia in light of a Late-Proterozoic plate collision. In: Tobi, A.C. \& Touret, J.L.R. (eds.): The deep Proterozoic crust in the North Atlantic Provinces. Reidel, Dordrecht, pp. 309-322. https://doi.org/10.1007/978-94-009-5450-2_18

Frost, B.R., Barnes, C.G., Collins, W.J., Arculus, R.J., Ellis, D.J. \& Frost, C.D. 2001: A geochemical classification for granitic rocks. Journal of Petrology 42, 2033-2048.

https://doi.org/10.1093/petrology/42.11.2033 
Kars, H., Jansen, J.B.H., Tobi, A.C. \& Poorter, R.P.E. 1980: The metapelitic rocks of the polymetamorphic Precambrian of Rogaland, SW Norway. Part II. Mineral relations between cordierite, hercynite and magnetite within the osumilite isograd. Contributions to Mineralogy and Petrology 74, 235-244. https://doi.org/10.1007/BF00371693

Laurent, A.T., Bingen, B., Duchene, S., Whitehouse, M.J., Seydoux-Guillaume, A.-M. \& Bosse, V. 2018a: Decoding a protracted zircon geochronological record in ultrahigh temperature granulite, and persistence of partial melting in the crust, Rogaland, Norway. Contributions to Mineralogy and Petrology 173:29. https://doi.org/10.1007/s00410-018-1455-4

Laurent, A.T., Duchene, S., Bingen, B., Bosse, V. \& Seydoux-Guillaume, A.-M. 2018b: Two successive phases of ultrahigh temperature metamorphism in Rogaland, S. Norway: Evidence from Y-inmonazite thermometry. Journal of Metamorphic Geology 36, 1009-1037. https://doi.org/10.1111/ jmg. 12425

Liégeois, J.P., Vander Auwera, J. \& Duchesne, J.C. 2002: Post collisional and anorogenic, alkaline and anorthositic magmatism: links with (meta)craton boundaries and crustal tongues (invited lecture), Norfa Nordic Network, Mariehamn, Finland. Abo Akademi Report, Mariehamn, Finland, p. 8-11.

Maijer, C. \& Padget, P. 1987: The geology of southernmost Norway. An excursion guide. Norges Geologiske Undersøkelse Special publication 1, 109 pp.

Marker, M., Schiellerup, H., Meyer, G.B., Robins, B. \& Bolle, O. 2003: Geological map of the Rogaland anorthosite Province (at scale 1:75,000). In: Duchesne, J.C. \& Korneliussen, A. (eds.): Ilmenite deposits and their geological environments. Norges Geologiske Undersøkelse Special publication 9, 138 pp.

Möller, A., O'Brien, P.J., Kennedy, A. \& Kröner, A. 2002: Polyphase zircon in ultrahigh-temperature granulites (Rogaland, SW Norway): constraints for $\mathrm{Pb}$ diffusion in zircon. Journal of Metamorphic Geology 20, 727-740. https://doi.org/10.1046/j.1525-1314.2002.00400.x

Pearce, J.A. \& Cann, J.R. 1973: Tectonic setting of basic volcanic rocks determined using trace element analysis. Earth and Planetary Science Letters 19, 290-300.

https://doi.org/10.1016/0012-821X(73)90129-5

Peccerillo, R. \& Taylor, S.R. 1976: Geochemistry of Eocene calc-alkaline volcanic rocks from the Kastamonu area, northern Turkey. Contributions to Mineralogy and Petrology 58, 489-502.

https://doi.org/10.1007/BF00384745

Roberts, N.M.W., Slagstad, T., Parrish, R., Norry, M.J., Marker, M. \& Horstwood, M. 2013: Sedimentary recycling in arc magmas: geochemical and $\mathrm{U}-\mathrm{Pb}-\mathrm{Hf}-\mathrm{O}$ constraints on the Mesoproterozoic Suldal Arc, SW Norway. Contributions to Mineralogy and Petrology 165, 507-523.

https://doi.org/10.1007/s00410-012-0820-y

Schärer, U., Wilmart, E. \& Duchesne, J.C. 1996: The short duration and anorogenic character of anorthosite magmatism: $\mathrm{U}-\mathrm{Pb}$ dating of the Rogaland complex, Norway. Earth and Planetary Science Letters 139, 335-350. https://doi.org/10.1016/0012-821X(96)00033-7

Scoates, J.S. \& Chamberlain, K.R. 1997: Orogenic to post-orogenic origin for the 1.76 Ga Horse Creek anorthosite complex, Wyoming, USA. Journal of Geology 105, 331-343. https://doi.org/10.1086/515928 
Shervais, J. 1982: Ti-V plots and the petrogenesis of modern and ophiolitic lavas. Earth and Planetary Science Letters 59, 101-118. https://doi.org/10.1016/0012-821X(82)90120-0

Shumlyanskyy, L., Hawkesworth, C., Billström, K., Bogdanova, S., Mytrokhin, O., Romer, R., Dhuime, B., Claesson, S., Ernst, R., Whitehouse, M. \& Bilan, O. 2017: The origin of the Palaeoproterozoic AMCG complexes in the Ukrainian Shield: new U-Pb ages and Hf isotopes in zircon. Precambrian Research 292, 216-239. https://doi.org/10.1016/j.precamres.2017.02.009

Slagstad, T., Roberts, N.M.W., Coint, N., Høy, I., Sauer, S., Kirkland, C.L., Marker, M., Røhr, T.S., Henderson, I.H.C., Stormoen, M.A., Skår, Ø., Sørensen, B.E. \& Bybee, G.M. 2018: Magma-driven, high-grade metamorphism in the Sveconorwegian Province, southwest Norway, during the terminal stages of Fennoscandian Shield evolution. Geosphere 14, 861-882. https://doi.org/10.1130/GES01565.1

Slagstad, T., Roberts, N.M.W., Marker, M., Røhr, T.S. \& Schiellerup, H. 2013: A non collisional, accretionary Sveconorwegian orogen. Terra Nova 25, 30-37. https://doi.org/10.1111/ter.12001

Streckeisen, A. 1974: How should charnockitic rocks be named? In: Bellière, J. \& Duchesne, J.C. (eds.): Géologie des domaines cristallins. Société Géologique de Belgique, Centenary volume, Liège, pp. 349-360.

Streckeisen, A. 1976: To each plutonic rock its proper name. Earth-Science Reviews 12, 1-33. https://doi.org/10.1016/0012-8252(76)90052-0

Sun, S.S. \& McDonough, W.F. 1989: Chemical and isotopic systematices of oceanic basalts: implications for mantle composition and processes. In: Saunders, A.D. \& Norry, M.J. (eds.): Magmatism in Ocean Basins. Geological Society of London Special Publication 42, pp. 313-345. https://doi.org/10.1144/GSL.SP.1989.042.01.19

Taylor, S. \& McLennan, S. 1985: The continental crust: its composition and evolution. Blackwell, Oxford, $312 \mathrm{pp}$.

Tobi, A.C., Hermans, G.A.E.M., Maijer, C. \& Jansen, J.B.H. 1985: Metamorphic zoning in the high grade Proterozoic of Rogaland-Vest Agder, SW Norway. In: Tobi, A.C. \& Touret, J.L.R. (eds.): The deep Proterozoic crust in the North Atlantic Provinces. Reidel, Dordrecht, pp. 477-497.

https://doi.org/10.1007/978-94-009-5450-2_28

Vander Auwera, J. 1993: Diffusion controlled growth of pyroxene-bearing margins on amphibolite bands in the granulite facies of Rogaland (Southwestern Norway): implications for granulite formation. Contributions to Mineralogy and Petrology 114, 203-220. https://doi.org/10.1007/BF00307756

Vander Auwera, J., Bolle, O., Bingen, B., Liégeois, J.-P., Bogaerts, M., Duchesne, J.-C., De Waele, B. \& Longhi, J. 2011: Sveconorwegian massif-type anorthosites and related granitoids result from postcollisional melting of a continental arc root. Earth Science Reviews 107, 375-397.

https://doi.org/10.1016/j.earscirev.2011.04.005

Vander Auwera, J., Bolle, O., Dupont, A., Pin, C., Paquette, J.-L., Charlier, B., Duchesne, J.-C., Mattielli, N. \& Bogaerts, M. 2014a: Source-derived heterogeneities in the composite (charnockite-granite) ferroan Farsund intrusion (SW Norway). Precambrian Research 251, 141-163.

https://doi.org/10.1016/j.precamres.2014.06.003 
Vander Auwera, J., Charlier, B., Duchesne, J.-C., Bingen, B., Longhi, J. \& Bolle, O. 2014b: Comment on Bybee et al. (2014): Pyroxene megacrysts in Proterozoic anorthosites: Implications for tectonic setting, magma source and magmatic processes at the Moho. Earth and Planetary Science Letters 401, 378-380. https://doi.org/10.1016/j.epsl.2014.06.031

Vander Auwera, J., Longhi, J. \& Duchesne, J.C. 1998: A liquid line of descent of the jotunite (hypersthene monzodiorite) suite. Journal of Petrology 39, 439-468. https://doi.org/10.1093/petroj/39.3.439

Wendlandt, R.F. 1981: Influence of $\mathrm{CO}_{2}$ on melting of model granulite facies assemblages: a model for the genesis of charnockites. American Mineralogist 66, 1164-1174.

Wilmart, E. \& Duchesne, J.C. 1987: Geothermobarometry of igneous and metamorphic rocks around the Åna-Sira anorthosite massif: implications for the depth of emplacement of the South Norwegian anorthosites. Norsk Geologisk Tidsskrift 67, 185-196.

Wiszniewska, J., Claesson, S., Stein, H.J., Vander Auwera, J. \& Duchesne, J.C. 2002: The north-eastern Polish anorthosite massifs: petrological, geochemical and isotopic evidence for a crustal derivation. Terra Nova 14, 451-460 https://doi.org/10.1046/j.1365-3121.2002.00443.x 